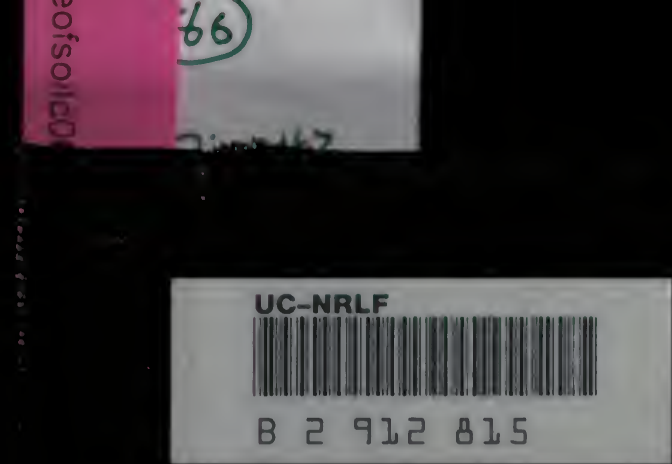




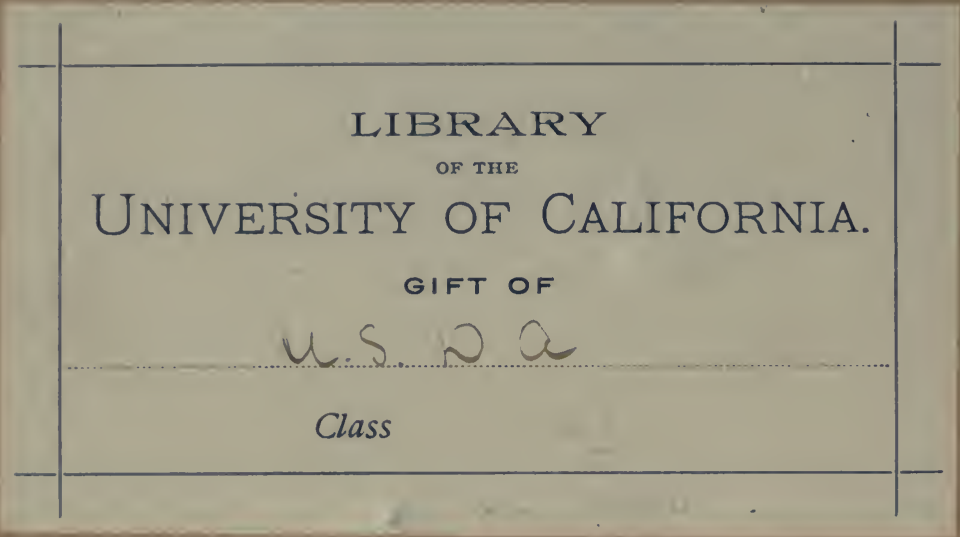




Digitized by the Internet Archive in 2007 with funding from Microsoft Corporation 
U. S. DEPARTMENT OF AGRICULTURE, BUREAU OF CHEMISTRY - BULLETIN N0. 76.

H. W. WILEY, Chiefof Bureru.

\section{INSECTTOTDE STEDIES.}

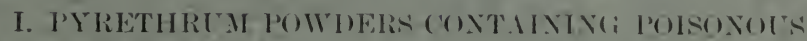
METAL.

I1. I (UMPHLATION (IF ANALYSE OF INELTICIDES ANI) FINGI(II)E.

HI. NTATE LAWS GONERNINC: TIIE (OMPONITION ANI) SALE OF IXSECTICIIES.

.T. T. ILAY IVOCD,

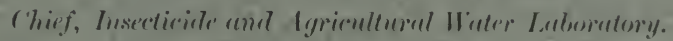

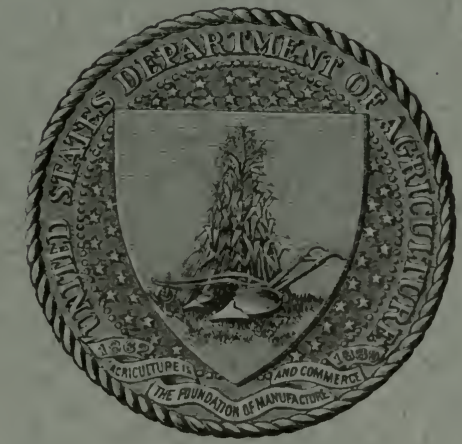

WASHINGTON:

GOVERNMENT PRINTING OFFICE

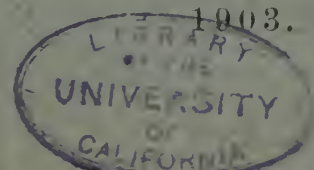


U. S. DEPARTMENT OF AGRICULTURE, BUREAU OF CHEMISTRY - BULLETIN NO. 76.

H. W. WILEY. Chief of Burenu.

\section{INSECTICIDE STUDIES.}

I. PYRETHRLN POWDERS CONTAINING POISONOUS METALS.

II. A COMPILATION OF ANALYSES OF INSECTICIDES AND FUNGICIDES.

III. STATE LAWS GOYERNING THE COMPOSITION AND SALE OF INSECTICIDES.

BY

\section{J. K. HA YWOOD,}

Chief, Insecticide and Agricultural Water Laboratory.

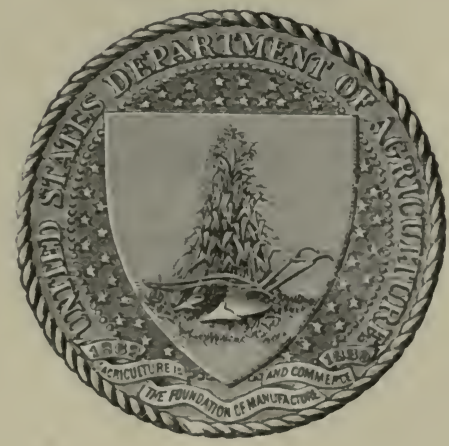

WASHINGTON:

GOVERNMENT PRINTING OFFICE.

1903. 



\section{LETTER OF TRANSIITTAL.}

U. S. Departmext of Agriculture.

Bureau of Chemistry,

Wasleington, D. C., Marrlh 1.\%, 1903.

SIn: I have the honor to transmit for your approval three papers on insecticides prepared in the Insecticide and Agricultural Water Laboratory of this Bureau, and to recommend their publication as Bulletin No. 76 of the Bureau of Chemistry.

Respectfully.

H. W. WILFY,

Hon. JAMES WILsoN,

('rict:

Secretary of Agriculture. 


\section{CONTENTS.}

I. Pyrethrum powders containing poisonous netals .................

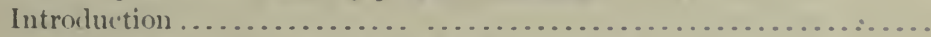

Cases of poisoning hy lead and other chrontates .................

Lead poisoning cansed by the manufacture of fuses for lighting purposes.

Fatal poisoning hy eating confectionery colored with learl (his).

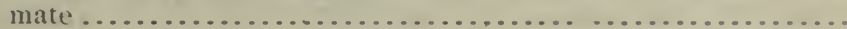

Fatal poisoning by inhaling dust from yam colored with lear chromate

l'uge.

Memoirs concerning dangers to which workmen in chromate futories are exposed . . . . . . . . . . . . . . . . . . . . . . . . . . .

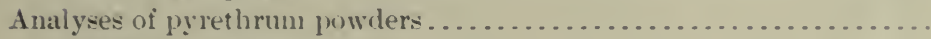

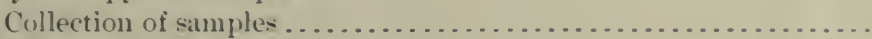

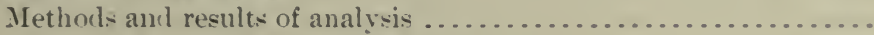

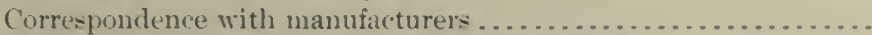

II. A compilation of analyes of insecticides and fungicides. . . . . . . . . .

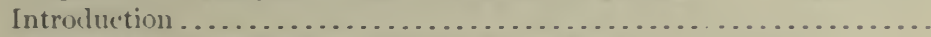

Sources of analyses and description i is sam les...................

Paris greens.

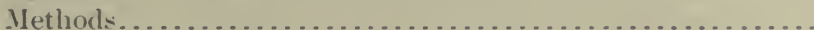

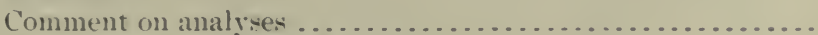

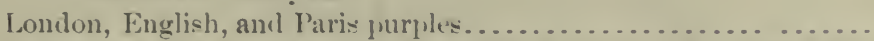

Insecticides aid fungiciles other than Paris Green and London I'urple that contain arsenic or copper, or loth as active constituents.

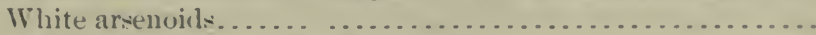

Paris Green and Boritedux Mixture....................

Slug shots .................................

Peroxid of silicates . . . . . . . . . . . . . . . . . . . . . . .

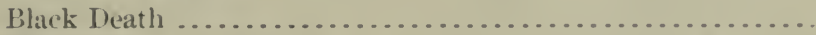

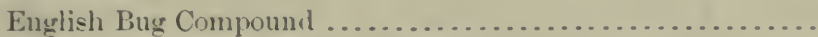

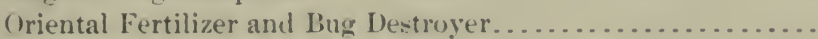

Lead Arsenate and Pink Arenoid . . . . . . . . . . . . . . . . .

X.X, Purple Poison, and Insecticide ....................

Copper carbronate. . . . . . . . . . . . . . . . . . . . . . . .

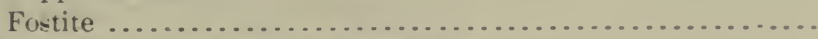

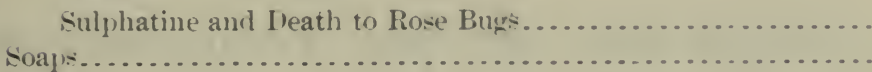

Lyes

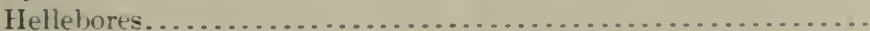

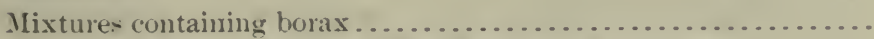

Hooker's Cockroach and Water Bug Exterminator .........

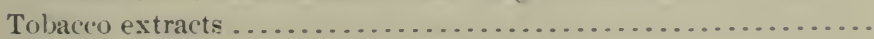

Formalins 
II. A compilation of analyses of insecticiles and fungicides-Continuerl.

Sources of analyses and description of samples-Continued.

Page.

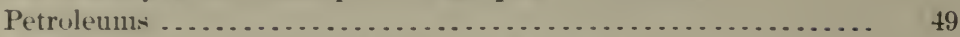

Miscellaneous solid insecticides and fungicides............. 50

Sulphurs.................................. 50

Pine-tar insecticides ............................ 50

Bug Deaths..................................... 50

Potassium cyanid ................................ 50

Nonpoisonous Potato Bug Destroyer ................... 51

Nonpoisonous Insect Exterminator ................... 51

X. O. Dust............................................ 51

Electric Vermin Exterminator ...................... 52

- Par' Oidium .................................... 52

Antinonnin ....................................... 52

Miscellaneous liquid insecticides and fungicides ............ 52

Bollene Insecticide .............................. 52

Excelsior Insecticide and Wood Preserver, Rerl Cedar brand.. 54

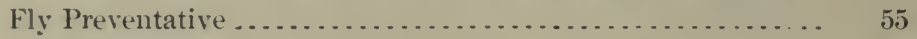

Karbo-Kresolate ............................... 55

Professor De Graff's Carpet Bug Destroyer ............. 56

III. State laws governing the composition and sale of insecticides........ 57

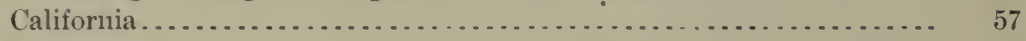

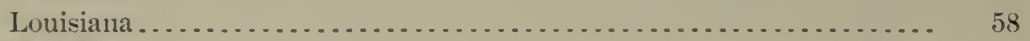

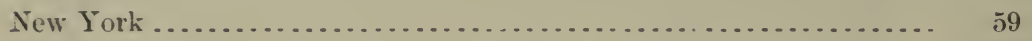

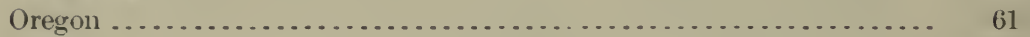

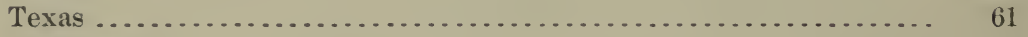

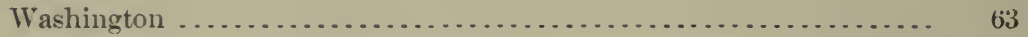




\section{INSECTICIDE STUDIES.}

\section{PYRETHRUM POWDERS CONTAINING POISONOUS METALS.}

\section{INTRODUCTION.}

In the course of a recent examination of a large number of miscellaneous insecticides it was observed that a number of pyrethrum powders contained lead chromate. These powders are sold under such names as Persian Insect Powder, Dalmatian Insect Powder, Buhach, and Pyrethrum, and are colored yellow because there seems to be a popular demand for this grade of goods, the public apparently believing that the preparation must be bright yellow in order to kill insects. As a matter of fact pure pyrethrum, which is composed of the ground flower heads of Pyrethrum roseum and Pyrethrum cinerarixfolium. usually possesses a light yellow color, but never the bright, intense yellow color given to it by lead chromate.

As lead chromate is known to be poisonous, it would appear that it is a very reprehensible practice to add it to pyrethrum powders, since they are often blown about living rooms with a bellows to kill insects, and are consequently inhaled by human beings. Besides this, pyrethrum is always adrertised to be harmless to human beings, which it is when pure, but ceases to be so when it has been mixed with lead chromate or other yellow colored chromates. In view of the above facts it was deemed advisable to examine the pyrethrum powders sold upon the American market to discover which of them contain yellow chromates and at the same time to cite cases of poisoning by chromates to substantiate the claim that any of the yellow chromates that might be used for this purpose, and especially lead chromate, are poisonous to human beings. The facts which have been collected on these points are embodied in the following report:

\section{CASES OF POISONING BY LEAD AND OTHER CHROMATES.}

Since it is not generally known that many pyrethrum powders contain lead chromate, it doubtless often happens that physicians are much puzzled as to the cause of the illness of persons who have been exposed to the action of such powders. In order, therefore, that physicians and others may recognize the symptoms of chromate 
poisoning caused by this class of goods, the following account is given of cases of chromate poisoning found in medical records:

\section{LEAD POISONING CATSED BY THE MANUFACTURE OF FUSES FOR}

\section{LIGHTING PURPOSES. "}

On February 22, 1875, a woman of about 46 years of age came under my care at the hospital. She complainer of pains in the stomach and a general indisposition or breaking down. For a number of days she had suffered with severe gripes. Her stomach was not swollen, but her skin was very sensitive and palpation caused a contraction of the abdominal muscles. There was, however, no tumor in the abdominal cavity. She had suffered for about fifteen days with obstinate constipation that could be relieved only by an injection; her liver was small and not painful; her tongue white, appetite nearly entirely lacking, and breath foul. There was nausea and a distaste for foor, and one could observe the existence of a grayish-black slatecolored border on the edgres of her teeth next to the gums, which had all the characteristics of lead bands. That symptom, added to the gripes and to cramps in the calves of the legs during the night, causerl me to diagnose the case as leat poisoning. This woman was under my care until the 16th of March, at which time she began to convalesce, although at that time she was still anæmic and feeble; but there was unquestionable improvement.

Being well convinced that my patient was suffering with lead poisoning, I thought I ought to find the cause. I found that she had worked for five years in a well-aired factory employing about 30 people, where they were engaged in the manufacture of fuses which were to be used by smokers to light their pipes and cigars. Her work differed from that of her fellow-workers in that she was employed in winding the cotton that was to be used for the manufacture of fuses, while they wove the threads. of cotton. She was thus more exposerl than her companions to the emanating dust, especially as the cold weather had obliged them to close the windows of the shop. These fuses were about as large around as a pencil or the little finger and of a yellowish orange color, indicating that they were colored with lead chromate. I chemical analysis showed the presence of this compound.

At the shop where these fuses were manufactured I found that those who were engaged in weaving them did not show any appreciable symptoms of lead poisoning, while those who were employed to shake out and wind the cotton all had fairly well developed cases. The merchant at Paris who manufactured these fuses said that they were originated in Germany, but were now exported largely, especially to Anerica.

FATAL POISONING BY EATING CONFECTIONEIR COLORED WITI LEAD CHROMATE."

On March 14, 187-, between 9 and 11 a. m., the two sons of Mr. H., aged respectively $3 \frac{1}{2}$ and 13 years, ate several small ornaments representing bees that har been placed on a cake. In the affernoon of the same day they became very ill and were attacked with severe vomiting and great prostration. The vomited mass was at first yellow, and was thrown up with great pain. Vomiting continued until $11 \mathrm{p} . \mathrm{m}$., after which it hecame inf requent. When the physician arrived, at $6 \mathrm{p}$. m., they were in berl and suffering extremely. They had redlened faces, complained of great thirst, were languid, had no dysentery, although they complained of slight pains.

a Annales d'hygiène, 2d scries, No. 44, 1s75.

$b$ Vierteljahresschrift für gerichtl. Medizin, 1sit, ㅇ: 60 . 
It was easy to see that they had been poisoned, and sinere in the morning they had eaten the same food as the rest of the household, who remained in perfect health, probably the poisoning was due to the above-mentioned bees, seven of which har been given to the children to play with, while only one eould be found. They finally confessed that they had eaten the remaining six, and the nurse harl secen then do it. The nurse thinking it night be harmful, harl taken at softened "bee" from the younger chilul and wiped out his numth.

One of the "bees," of which more were found at the confectioner's who harl rade the rake, was exannined hy a chemist and found to consist of gum and lead chromate. On the following day both patients had the same red an 1 heated faces; they showed no interest, and on being questioned gave tokens of displeasure. They did not complain of local pains, evidently because their senses were benumbed. The younger had some diarrhea and toward noon eonvulsions, from which his face was livit. The convulsions beame nore frequent toward evering, and at 9 s'clock on the morning of the following day, March 16, the younger boy died.

The older child still had a red, heated face and displayed no interest, being almost unconscious. The skin upon his breast and abdomen was strikingly red. The evening temperature was $39.5^{\circ}$ in the armpits. On the 17 th the pulse was irregular and the temperature in the evening $39.65^{\circ}$. Drinking was extremely painful, in spite of great thirst. On the 1 stli a foul smell came from the mouth, relness was still present, accompanied by stupidity and painful swallowing; temperature in the evening was $39.2^{\circ}$. On the 19 th a collapse took place, a very foul smell came from the mouth, and swallowing was almost impossible. The senses were very much benumberl, an! death followed at $11 \mathrm{a} . \mathrm{m}$. The result of the post-mortem may be summel up in the words of the physician as follows: "The death of the children is the direct result of the destruction which has hefallen the digestive canal from the throat to the luodenum. Concerning the cause of this destruction and concerning some further conditions we will not express an explicit opinion." The liver, stomach and contents, and urine were then subjected to a chemical examination. This gave negative results, except that in the liver of both corpses traces of copper were found, a discovery of no toxological interest. The alsence of all poisonous metals in all other part sof the corpses was shown.

The "bees" were also examined, and 0.27 gram of gum and 0.0042 gram of neural lead chromate were found in one that was $13 \mathrm{~mm}$ long and $5 \mathrm{~mm}$ thick. The powder used by the confectioner was also analyzed and found to contain lear chromate. The illness of both children, occurring at the sime time and showing itself ly severe romiting, must be traced back to their eating some poisonous fool; and since it was known that they both ate the "bees" which contained lead chromate and that they vomited up yellow romit, the eating of the metallic salt must be considered as the cause of the deaths.

It is not remarkable that no learl chronate was fuund in the alimentary tract, since the children vomited a great deal and thus threw up all of the poison.

FATAL POISONING BY INHALIN( DLST FROM YARN COLORED WITH LEAD CHROMATE."

On December 29, 1876, a weaver, B., at E., receiverl a package of yellow threads, colored with lead chromate, which were to be used for the manufacture of eurtains. B. and his mate, G., worked at one spool and Mrs. B. and a girl, I., at the other. They worker from 7 a. $m$. to 10 and 11 p. m. While they were working the threarls shed powder, according to B.'s statement, so that their faces and hair became entirely 
yellow: Their spittle appeared yellow, and the powler had a bitter taste. According to Mrs. B. the powder had a sweetish-bitter taste. The male helper sickened after working upon the threads about eight days; he had a headache, with a ringing in the ears, pains in his breast and stomach, and lost his appetite. He had a desire to romit and was constipated. This continuerl for six weeks, until he ceased working and went to the doctor. Mrs. B. during the meantime became ill; she complained of loss of appetite and pains in the chest. B. on the last day of the third week of the work was attacked with pains in the stomach. Then appeared nausea, languor, and sleeplessness. Eight or ten days later he was obliged to stop work and send for the doctor on account of pains in the bowels and costiveness. The girl helper was also ill, having diarrhea, loss of appetite, and pains in the breast.

Dr. J. stated the symptoms of B. and the helpers in the following terms: Yellowcoaterl tongue and yellow expectoration, entire loss of appetite, nausea, temporary romiting, and pains in the region of the navel, accompanied by obstinate constipation. The excrement was also colored yellow, and all the patients were very weak. The doctor stated that these symptoms were all caused by breathing yellow dust from the yarn and indicated plainly lead-chromate poisoning.

Although all of the above-mentioned persons finally recovered, B. lost a 9-weeksold baby, whose death could be ascribed only to the breathing or swallowing of the yarn dust. When the B.'s noticed how much dust was flying about they sought to protect their baby by spreading a white woolen cloth of medium thickness over his face. This cloth was said to have been yellow with the dust all the time, as well as the bed on which the child was lying. The child's crib stood midway between the two B.'s stools and at night the mother took the child to bed with her. It was healthy and lively, so that continued poor feeding could not have caused the bad condition of the stomach (jelly-like softening and perforation) observerl at the postmortem. Suddenly, six or eight days before its death, which occurred on February 24 , the child was taken sick. Its face became pale and its body hot. It had a couple of loose, yellow actions each day, which were accompanied by restlessness and frequent screaming. The, skin upon the breast and stomach became rerl. In the beginning the baby drank, but refused to eat; later it drank with trouble, and on the day it died it swallowed with difficulty. The lips were dry, the breathing short, and death followed slowly. It is to be remarked that the child, after remaining healthy for six weeks in spite of the surrounding yarn dust, was suddenly taken sick six or eight days before death and grew worse at a time when the yellow yarn was not being worked upon. Since the child remained covered with the cloth up to the time of its death, it appears likely that the dust gradually worked its way through the cloih and sifted down so that the child always had to breathe this impure air until its death.

A chemical examination was made of the following organs of the child and the articles that were used at the the time of lis death: Contents of the nose, contents of the stonach, urine and gall taken from the urine and gall bladders, organs of the stomach and breast, the hair of the head, shirt slip, the child's nipple, and a portion of the yellow yarn. The brain would have been examined, but the vessel containing it was lost. The yarn contained 11.83 per cent lead chromate. Learl chromate was found in the liair of the hearl, and the little slip contained $65 \mathrm{mg}$ lightly strewn over it. The organs of the neck, chest, and gullet contained $36 \mathrm{mg}$ of learl chromate. The other fluids of the body and organs, the shirt, and nipple did not show the presence of any learl chromate.

It will thus be seen that numbers of authentic cases of poisoning, by either breathing or swallowing lead chromate, are on record. Following will be found several typical cases of poisoning by alkaline 
chromates and bichromates selected from the large number that hare been observed by Messi's. Delpech and Hillaire: ${ }^{a}$

MEMOIRS CONCERNING DANGERS TO WHICH WORKMEN IS CHROMATE FACTORIFA ARF H.XPOSED.

Onsenvation I.-Workmen employed for a long time at the grinder (pilerie) and formerly at the kettles (chaudirers) -Nasal partition perforated by the dust.

V., agred 50, has worked for twelve years (i849) in a chromate manufacturing plant. He was employer from the heginning at the grinder and sifter, and is thus constantly enveloper in an atmosphere chargerl with fine chrome-iron powder. He says that he feels no indispusition. He wipes his nose and spits blackish matter, but neither coughs nor has any smothered feeling; his health appears to be good; he has no disease of the lungs; he does not believe there is anything the matter with his nose; however, his sense of smell was perfect when he entered the factory, and he has now completely lost it. The nasal passages were examined, and a perforation of the cartilage was observed. He says that since entering the factory he has sometimes worked at the kettles. At the commencement of this labor he was attacked with headache and swelling of the nose accompanied hy an abundant discharge from the nostrils. His eyes did not smart. These symptoms lasted about fifteen days, after which he regained the most perfect health without even experiencing again the symptoms enumerated, although employed at the same work.

This workman has since (October, 1864) died after a few days' illness of inflammation of the chest, without having previously shown any prolonged symptoms of suffering with the respiratory organs.

OBsenvatiox III.-Workman employed at the kettles for about four veeks-Inflammation of the mucous membrane of the nose-Sore upon the right thumb-A nasal perforation-Clceration of both of the external nasal walls.

E., aged 28, who had a good constitution, had been employed for five weeks in a potassium bichromate manufacturing plant when he was examined by us. He was employed about eight days insile the works carrying the bichromate and for three weeks at the kettles. From the first day he was attacked by prolonged and intense sneezing. After four days he suffered greatly with intense prickling, abundant running of the nose, an incessant desire to blow his nose, and the passage of red membraneous shreds. He had no watering of the eyes, or at most it was slight. The most serere symptoms lasted from ten to twelve days. He harl nearly recovered when he stopped working at the kettle, and has since completely recovered. This workman still has his sense of smell. He was aftlicterl by a sore on his right hand, caused by penetration of particles of bichromate in a slight excoriation, and a slight ulceration still remains. One can also note brown spots, causerl by sores of the same nature, upon the side of his face and on the ring finger.

E. has never suffered with his feet. He has no eruption either on the skin of his body or genital organs. His eyelids are not excoriated, and he has neither vomited, suffered with diarrhea, nor a cough. The nasal partition is perforated at the usual place.

a Annales d'Hygiène Publique et de Medicine Legale, 1869, and 1876, $2 \mathrm{~d}$ series. 
OBsERVATION VI.-Workman, a coppersmith unaccustomed to the manufacture of chromate, was exposed to the dust resulting from the repairing of the liettles-Inflammation of the mucous membrane of the nose and nasal perforation.

F., a coppersmith and a stranger to the chromate factory, came into the factory for a short time to repair the kettles. This repairing required a readjusting of the sides by hitting with a hammer, and these hlows ansed the crust of bichromate that adheres in the slightest irregularities to fly about in the form of a dust. He was attacked quickly hy inflammation of the mucous membrane of the nose and lost his nasal partition in eight dayss.

Onsenvatiox XI.-Superintendent, not employed at any special uork-1"7ronic irritution, suelling of the membrane at the usual place, but no perjoration.

O., aged 20 (December, 1863), has been employerl for four years in the chromate works. He has never workerl at the kettles or the calciner. Chargerl with general surveillance, he merely walks throngh the works; in exceptional cases, however, he helps soluter the leat crystallizing vats that are in neerl of repairs. He has consequently to a certain extent been subjected to the action of bichromate. At the time we examined him he had felt a tingling of the nose and had frequent fits of sneezing, but his nasal membrane had not been barly inflamerl. His nasal partition is not perforater, but at the usual point he has a slight swelling and reddening of the membrane. His general health is goorl.

Onsemvation XVIII.-Firman exposed to chromate dust-Perforation of the nasal catilage, ilcerated sores on the right hand.

I., aged 28, has been employed at the works for two years, and for the last ten months at the manufacture of potassium chromate. He is employed as a fireman, but often helps his fellow-workmen, and so luring much of the time spent in the factory he is exposed to chromate dust. He had always enjoved the best of health. He had never had syphilitic symptoms, but during his infancy the glands at the side of his neck were swollen for a long time. His general condition is gool. He had worked at the manufacture of potassium chromate for scarcely fifteen days when he was taken with nose bleeding, sneezing, pain in the nose, and watering of the eyes. He sometimes experienced a little uneasines in breathing. It was fifteen or twenty days after he had ceased to work at the preparation of potassium chromate that he examined his nose and found a small perforation. The nose preserves its normal form. There is an ulcer on the nasal cartilage in the right nostril, and at the edges of this the mucous membrane is very much inflamer. In the left nostril is an opening corresponding to this ulceration. His sense of smell is preserverl; neither the throat, palate, nor roof of the mouth have been attacked, and he has no eough. This workman has hard, eartilaginous, livil sears nuon his thumb and his right hand. On the left index finger there exists a sore which is much swollen and exudes a sero-purulent liquid. This workman has never harl any swelling or uleeration of his feet.

There are many other observations eited in the ahove article, but enough have been given to show that persons who are obliged to breathe air charged with the dust from chromates or bichromates are nearly always affected more or less seriously. 


\section{ANALYSES OF PYRETHRUM POWDERS.}

\section{COLLECTION OF SAMPLES.}

In order that samples of pyrethrum, representative of all grades, might be obtained, a circular letter was forwarded to the chemist of each of the experiment stations, with the request that they purchase for us, upon the open market, three or four samples of those products sold under the name of either Pyrethrum, Buhach, Persian Insect Powder, or Dalmatian Insect Powder. They were also asked to give data as to the price per two-ounce sample, the name and address of the retail dealer. and the name and address of the person who originally prepared the sample. In answer to these letters 105 samples were received, all of which were subjected to chemical examination. It is believed that these samples represent fairly well the present state of the American market.

Credit is due to the assistants in the laboratory, Bernard H. Smith and Harry W. Houghton, who aided in performing the analytical work.

\section{METHODS ANI) RESULTS OF ANALYSIS.}

Since lead, potassium, and barium ehromate have all a bright yellow color, and any of them might be used to color the pyrethrum powder's, tests for all of these substances were made in the samples under examination according to the following methods:

Qualitative test forr lear. - Ash about 2 grams of the sample in porcelain and treat with a little water and about 20 ce of concentrated hydrochloric acid in a porcelain dish. Place on the steam bath and steam for about one-half an hour or until all the lead is in solution and the chronium reduced and in solution. Filter after dilution. Add sodium carbonate until the solution is alkaline and then add acetic acid until the solution is just acid. Filter and add a solution of potassium chromate. A yellow precipitate or cloudiness indicates lead.

Qualitutice test for barium.-Ash about 2 grams of the sample in porcelain and treat with hydrochloric acid as directed for lead. Evaporate to dryness and take up with about 0.8 ec of hydrochloric acid. Filter and pass hydrogen sulphid through the filtrate. Filter off any sulphids that may precipitate and test for barium in the filtrate with a few drops of dilute sulphuric acid.

Qualitatice test for cliromium.-A sh about 2 grams of the sample in porcelain. Treat this with about four times it- weight of a mixture of equal parts of sodium carbonate and potassium nitrate, and fuse. Dissolve in water on the steam bath and filter. Make slightly acid with acetic acid and test with lead acetate for the presence of chromium.

Testing the powders by the above methods showed that whenever chromium was present lead was also present, these two evidently being combined as lead chromate. A quantitative estimation was also made of the chromium present according to the following method of analysis and the chromium was calculated to lead chromate. 


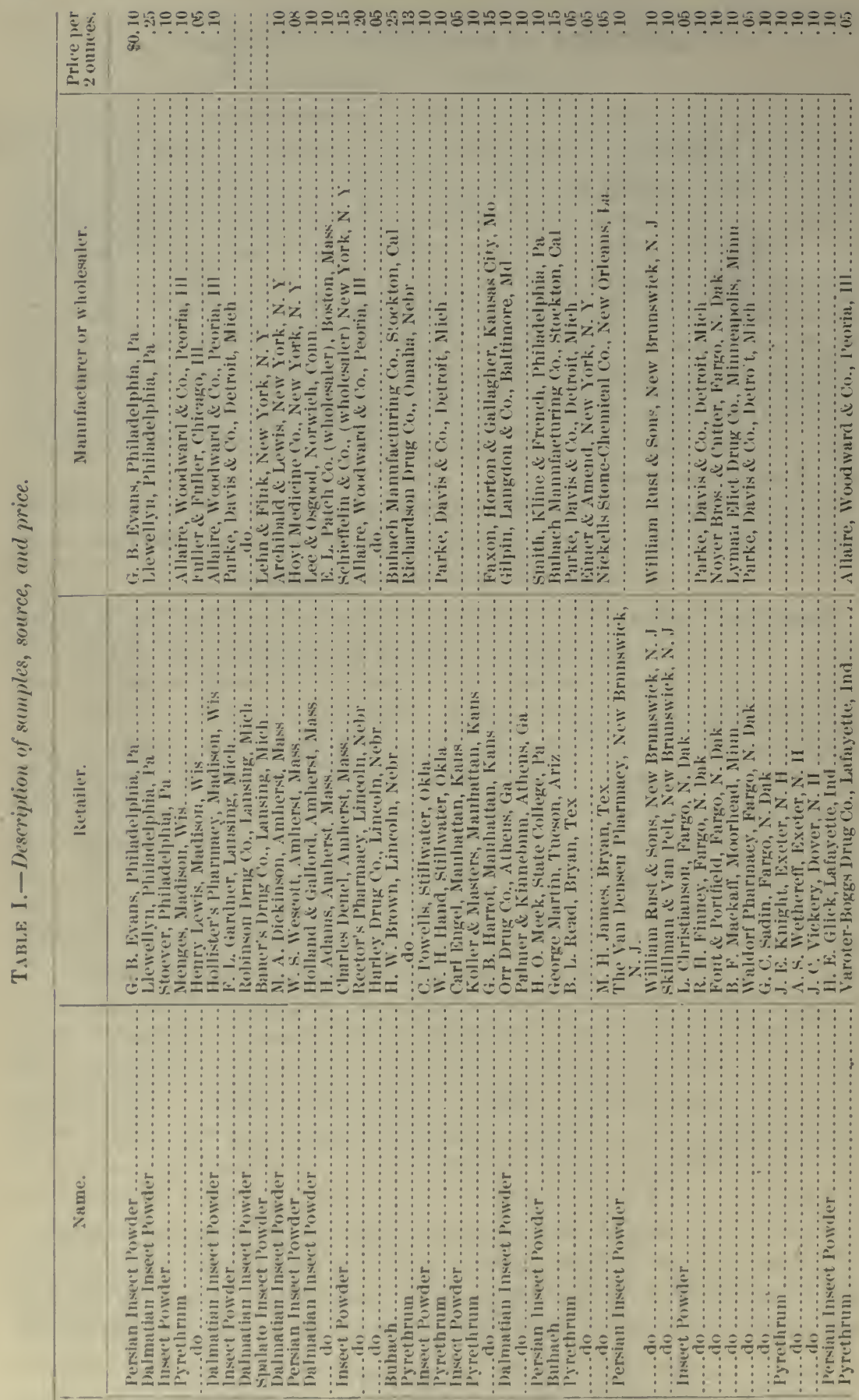

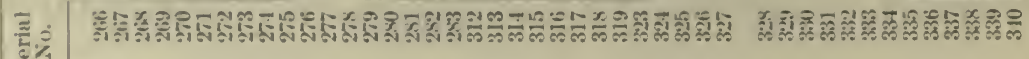




\section{$\bar{\vdots}$}

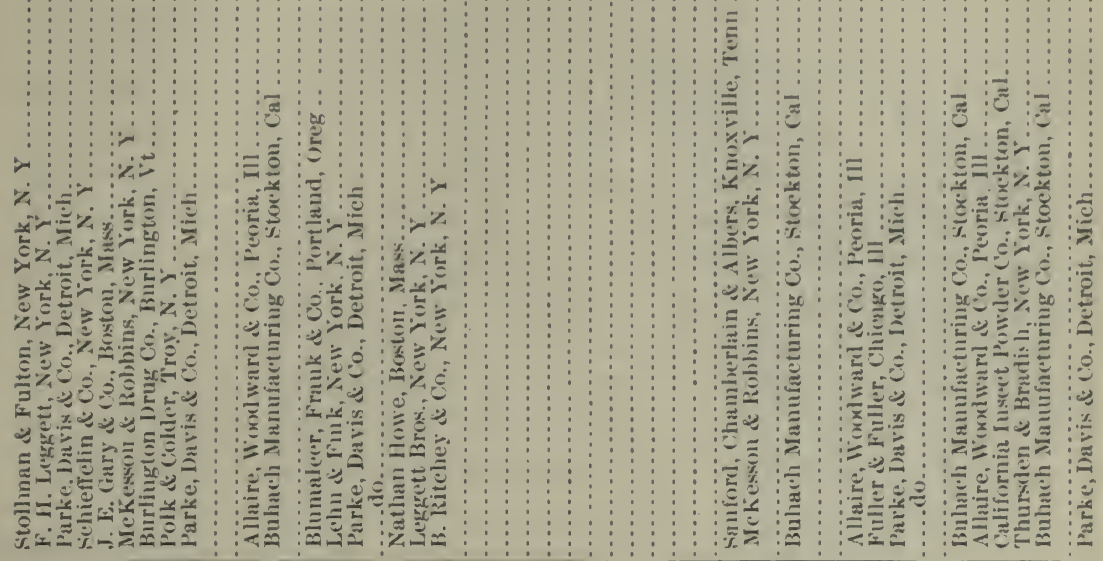

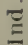

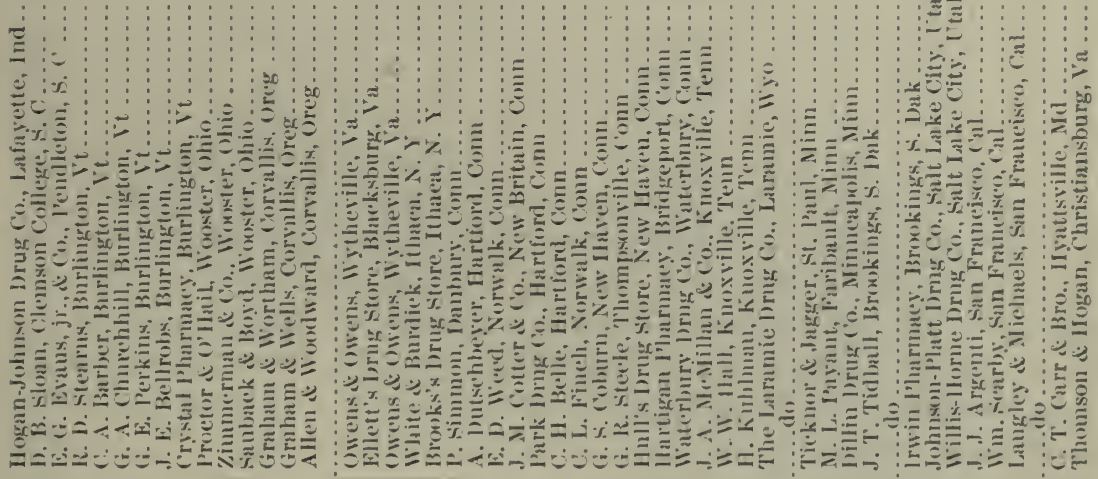

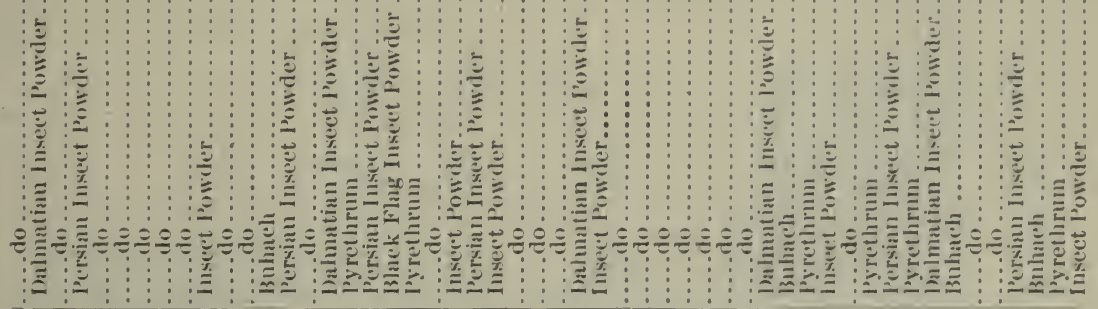

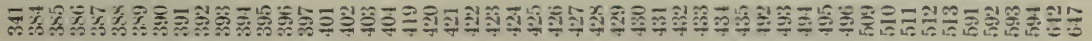




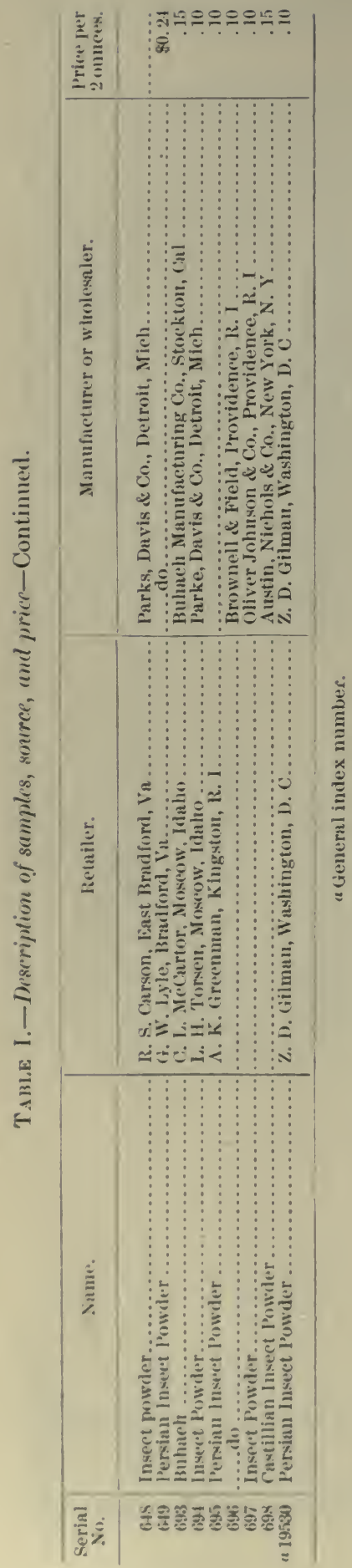


Method for determining chromicuril. - Weigh out from 2 to + grams of the sample. $A=h$ in a porcelain dish and allow to cool. 'Treat with a little water and a large amount of concentrated hydrochloric acid and evaporate to dryness. Treat again with concentrated hydrochloric acid and eraporate to dryness.

Take up the residue with abont 0.8 ce of concentrated hydrochloric acid with the aid of heat. Filter and pass hydrogen sulphid through the solution until all lead is precipitated. Filter and evaporate the filtrate to dryness. Take up the residue with a little water and $1 \mathrm{cc}$ of hydrochloric acid with the aid of heat. Precipitate out the chromium (with iron, aluminum, and some phosphoric acid) by means of ammonia, taking care not to add any excess of ammonia. Filter and wash with hot water. Dissolve the precipitate on the filter by means of hot dilute hydrochloric acid and evaporate to dryness. Take up with a little hot water and 6 to $S$ drops of concentrated hydrochloric acid, heating for a short time if necessary. Transfer to a 50 ce or 1 (1) ce llash and make up to the mark. Now prepare an alkaline permanganate solution in the following nanner: Make an approximately N 10 solution of potassium permanganate and standardize it against ammonium ferrous sulphate. Measure out exactly a liter of this solution and add a few grams of sodium carbonate and 1 gram of sodium hydroxid and make the entire rolume up to 2 liters. This is the standard solution required.

A convenient number of cubic centimeters of this standard is measured into a beaker and about 50 ce of distilled water, accompanied by a little sodium carbonate, is added. The solution of chromium previously prepared is then run in from a burette, while the contents of the beaker are boiling, until the pink color is dissipated and a pure yellow color results. Knowing the strength of the permanganate and the number of cubic centimeters of the chromium solution used, one can calculate the percentage of chromium in the original powder according to the following equation:

$$
\mathrm{CrCl}_{3}+\mathrm{KMnO}_{4}+ \pm \mathrm{KOH}=\mathrm{K}_{2} \mathrm{CrO}_{4}+\mathrm{MnO}_{2}+3 \mathrm{KCl}+2 \mathrm{H}_{2} \mathrm{O}
$$

In Table II are found the results ohtained upon the samples of pyrethrum powder examined:

TABLE II.-Examination of pyrethmem pouders for coloring matter."

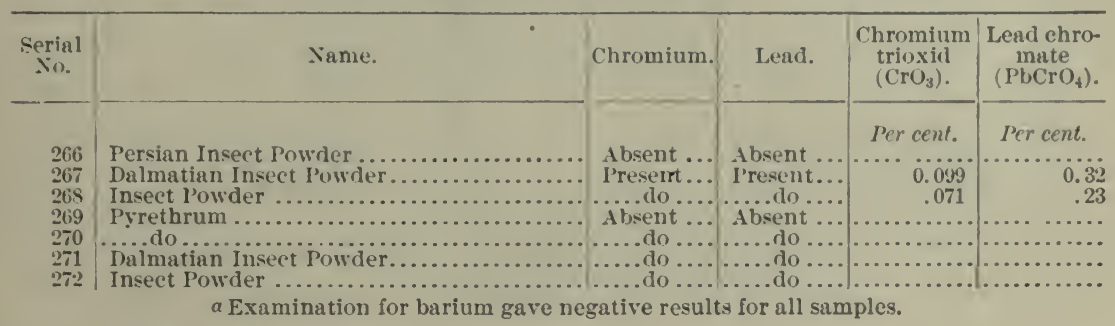


TABLE II.-Examination of pyrethrum pouders for coloring matter-Continued.

\begin{tabular}{|c|c|c|c|c|c|}
\hline $\begin{array}{c}\text { Serial } \\
\text { No. }\end{array}$ & Name. & Chromium. & Lead. & $\begin{array}{c}\text { Chromium } \\
\text { trioxid } \\
\left(\mathrm{CrO}_{3}\right) .\end{array}$ & $\begin{array}{c}\text { Lead ehro- } \\
\text { mate } \\
\left(\text { PbCrO }_{4}\right)\end{array}$ \\
\hline a 273 & Dalmatian Insect Powder & Present. & Present. & $\begin{aligned} \text { Per cent. } & \text {. Otis }\end{aligned}$ & er cent. \\
\hline 274 & Spalato Inseet l'owder & Absent. & Absent ... & & \\
\hline 275 & Dalmatian Inseet Powder & Present. & Present... & $130^{\circ}$ & \\
\hline 276 & Persian Inscet Powder. & Absent. & Absent ... & & \\
\hline 277 & Dalmation Insect l'owder & Present. & Present... & $.06 \mathrm{~s}$ & \\
\hline $\begin{array}{l}278 \\
279\end{array}$ & 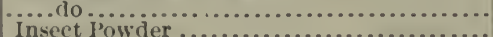 & Absent & Absent ... & & \\
\hline 280 & 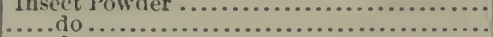 & …..do. & $\begin{array}{l}\text {...... do } . . . . \\
\ldots \text {... do } \ldots\end{array}$ & & \\
\hline 281 & Biudo do............. & & & & \\
\hline 282 & $\begin{array}{l}\text { Buhach } \ldots . . . . . . . \\
\text { Pyrethrim }\end{array}$ & do & ..do: & & \\
\hline 283 & 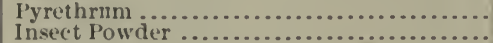 & & & & \\
\hline $\begin{array}{l}312 \\
313\end{array}$ & $\begin{array}{l}\text { Insect Powder .......... } \\
\text { Pyrethrum ............. }\end{array}$ & & . & & \\
\hline 314 & Inseet Powder ... & di & do. & & \\
\hline 315 & Pyrethrum ...... & Present & Present... & 124 & \\
\hline 316 & .... do ............ & .....do & ...... do.... & .102 & \\
\hline 317 & Dalmatian Insect Powder. & Absent. & Absent ... & & \\
\hline $\begin{array}{r}318 \\
a 319\end{array}$ & Fersian Insect Powder. & Present... & Present.... & .186 & \\
\hline 323 & 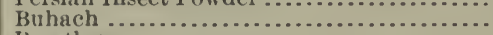 & Absent... & Absent... & .100 & \\
\hline 324 & I'yrethrum... & .....do.. & .... do .... & & \\
\hline 325 & ..... do $\ldots . . . . . . .$. & \#...do. & ..... do ..... & & \\
\hline $\begin{array}{l}3: 26 \\
327\end{array}$ & Persian Insect Powder... & $\begin{array}{l}\text { I'resent. } \\
\ldots . \text { do... }\end{array}$ & Present... & .251 & \\
\hline 328 & .... do ................... & Absent & Absent. & & \\
\hline $3: 29$ & ..... do ............ & Pre: & nt... & .421 & 1.36 \\
\hline 330 & Insect Powder ... & Absent ... & Absent ... & & \\
\hline 331 & ..... do ............. & ..... do..... & ......do ..... & & \\
\hline $\begin{array}{l}352 \\
333\end{array}$ & …...do do.............. & & $\ldots$ & & \\
\hline 334 & .....do............ & 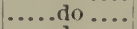 & . & & \\
\hline 335 & 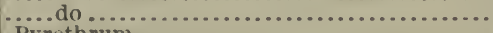 & & $\cdots \cdot$ & & \\
\hline 336 & Pyrethrmm ................ & H & ..... do .... & & \\
\hline 337 & 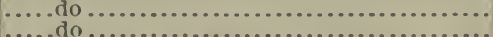 & 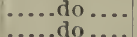 & ...... do... . & & \\
\hline $\begin{array}{l}3398 \\
339\end{array}$ & Persian Insect Powder.. & .....do .. & $\cdots \cdots$ & & \\
\hline$a 340$ & Pyrethrum ........... & Present. & Pre: & .090 & \\
\hline 31 & ....do do............. & Absent .. & Absent ... & & \\
\hline 384 & Dalmatian Inseet Powder. & ..... do .. & ...... do .... & & \\
\hline $\begin{array}{r}385 \\
a 386\end{array}$ & in Insect 1 owder. & Pre: & Present.... & .043 & \\
\hline 387 & Inse & Absent ... & nt ... & & \\
\hline 388 & Persian Insect Powder... & do. & ..... do .... & & \\
\hline 389 & 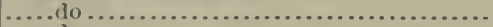 & & .....do .... & & \\
\hline 390 & .... do & ... & ...do. . & & \\
\hline $\begin{array}{l}391 \\
392\end{array}$ & 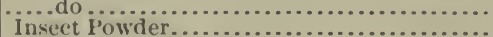 & $\ldots$ & ..... do ..... & & \\
\hline 393 & .... do ..................... & & & & \\
\hline 394 & 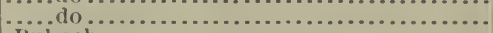 & $\cdots$ & … & & \\
\hline 395 & Buhach ................ & & & & \\
\hline 396 & $\begin{array}{l}\text { Persian Inseet I'owder } \ldots . \\
\ldots \ldots \text { do } \ldots \ldots \ldots \ldots \ldots \ldots\end{array}$ & do & do & & \\
\hline $\begin{array}{l}397 \\
401\end{array}$ & Dämatian Insect Pos & & & & \\
\hline 402 & $\begin{array}{l}\text { Daimat } \\
\text { Pyrethr }\end{array}$ & -..... & 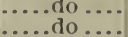 & & \\
\hline 403 & Persi & & & & \\
\hline 40 & eet I'owier & & .0 & & \\
\hline 419 & I'yrethrum ................ & I'resent. & Present... & .037 & \\
\hline 420 & & Hon & & .056 & \\
\hline 421 & & Absent & Absent ... & & \\
\hline 422 & Powder. & & ....do do... & & \\
\hline 423 & Insect Powder........... & Pre & Present... & .186 & \\
\hline 42 & ................... & $\mathrm{Ab}$ : & Absent ... & & \\
\hline $\begin{array}{l}425 \\
426\end{array}$ & $\ldots \ldots$ do $\ldots \ldots, \ldots$ & ......do do & ..... do .... & & \\
\hline $4: 27$ & t Pow & Pre & Pre & 362 & i. 17 \\
\hline $42 x$ & Insect I'owricr......... & Absent ... & Absent ... & & \\
\hline $4: 29$ & .....do. & ..... do & .... do ..... & & \\
\hline 430 & do. & & & & \\
\hline 431 & $\ldots \ldots \ldots \ldots \ldots, \ldots$ & & $\cdots$ & & \\
\hline 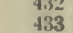 & n.................. & & & & \\
\hline 431 & .....do. & $\cdots$ & ... & & \\
\hline 435 & .....do & & do... & & \\
\hline 492 & Dalmatian Inseet Powder. & & & & \\
\hline 493 & rum & & & & \\
\hline $\begin{array}{l}494 \\
495\end{array}$ & $\begin{array}{l}\text { Pyrethrum } \\
\text { Insect Powder } \ldots \ldots \ldots \ldots \ldots \ldots\end{array}$ & & & & \\
\hline
\end{tabular}


T. вLE II.-Examination of pyrethrum pouders for coloring matler-Continued.

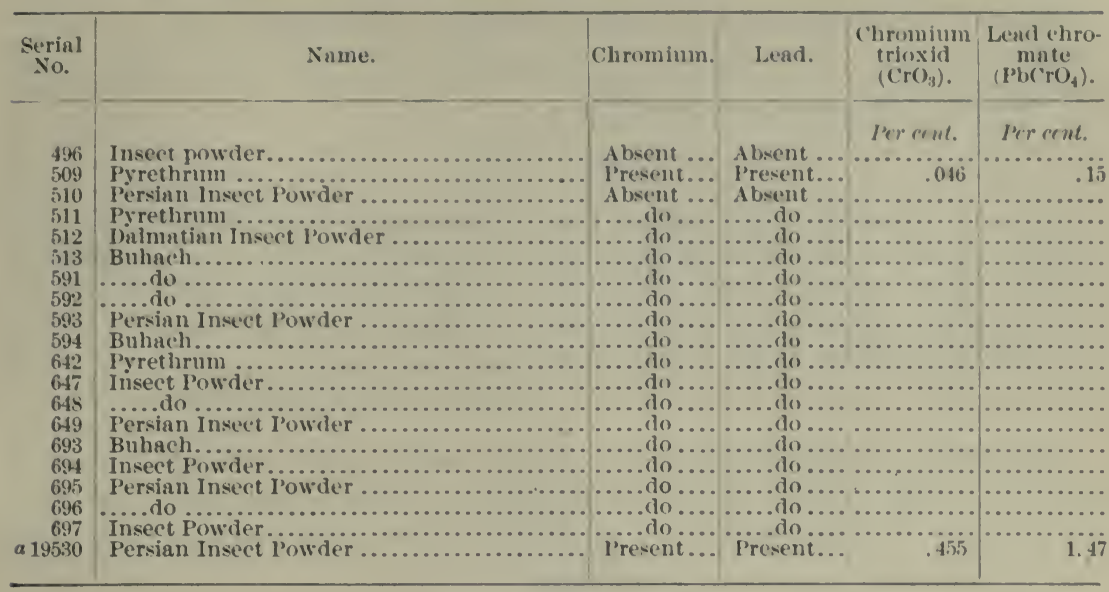

a General index number.

A glance at this table shows that wherever the powder's are colored by a foreign substance lead chromate is the compound used. Nineteen of the 10 s samples, or 18 per cent, were colored by lead chromate, the amount of which varied from 0.12 to 1.47 per cent.

Of the adulterated samples, 5 were sold under the name of Dalmatian Insect Powder, 5 under the name of Persian Insect Powder, 7 under the name of pyrethrum, and 2 simply as insect powder. It is also evident from Tables I and II that some firms are sending out two grades of pyrethrum, one containing lead chromate and the other not containing that substance. It is unfortunate that the names of all those who originally prepared the above samples could not be obtained since the powders containing the largest amount of lead chromate lack the name of the manufacturer with surprising regularity.

It seems hardly necessary to call attention to the widespread harm that is undoubtedly caused by powders thus colored. They are sold in all parts of the country and are especially adrocated to kill or drive away flies, fleas, cockroaches, and other household pests, and thus they are used principally in the home. Consequently they are breathed hy many people for days and weeks at a time. Such powders not only possess the poisonous characteristics of nearly all lead salts, but in addition have the toxic properties of chromic acid. It would appear. therefore, that the influence of lead chromate day by day no doubt occasions many of the mysterious cases of lead poisoning in which it seems impossible for the physician to find the source of the lead taken into the system.

\section{CORRESPONDENCE WITH MANUFACTURERS.}

In order that the manufacturers might have an opportunity to comment upon the analyses before they were published, a circular letter 
was sent to each one whose goods had been examined. giving him the results of our analysis and asking for any comments that he might desire to make. Such parts of the answers as throw any lighi upon the subject are given, as follows:

\section{Serial No. 340.}

* * * You say that the Varoter-Boggs Irug Company, of Lafarette, Ind., furnished you with a sample of our insect powder containing 0.29 per cent of lead chromate. If such is the case, they added the lead chromate themselves, as we do not use it. We do not color our insect powder, but leave that for the customers to do if their trade demands a highly colored powder.

Allaire, WOODWARn \& ('o.

Comment: It appears that the above sample was probably colored after it left the hands of the manufacturer, since seren other samples of Allaire, Woodward \& Co.'s goods (Nos. 269, 271, 280. 281, 394. 496, and 591) contained no lead chromate.

\section{Serial N\%. 2\%3.}

* * * From the manager of our importing department we also receive the positive assurance that the powder entering into your sample No. 273 could not possibly have contained learl chromate as it left the hands of his department. It goes without saying that we never add leut chromate or any other foreign substance to our insect powler and that the alulteration which you report must have been deliberately put into it by some interested person after it passed out of our possession.

\section{PARKE, DAVIS \& Co.}

Coinment: It appears from investigations which have been made that the above sample received the lead chromate after it left the hands of the manufacturer named, if indeed it were manufactured hy the firm originally. Fourteen other samples of Parke, Daris \& Co.'s goods (Nos. 272, 313, 331, 334, 355, 391, 402, 41)3, 510, 511, 647, 648, 6it9, 69t) contained no lead (hromate.

\section{Sirial Ni. 3S6.}

* * * Messrs. R. I. Stearns \& Co., Burlington, Vt., are in error as to the source of the Persian insect powder which they furnished your representative, stating that it came from our firm, and we have written them to that effect and askew for an explanation. We have examined their entire aceount for the year 1902, and positively state that they did not purchase any inseet powder of us, and if they had it would have been found to be perfectly pure, as we do not allow any adulteration of Persian powder sold by us.

SCHIEFFEIIN \& Co.

Comment: It is probahle that the retailer made a mistake in giring the source of his insect powder, since another sample furnished hy schieffelin \& Co. (No, 279) rontained no lead chromate.

Serial N\%. S1\%.

* * * We presume that this anal yis is approximately correct, and that therefore there is foreign matter in the insect powder amounting to a little over one-half of 1 per cent. This additional matter is undoubtelly added, not for the purpose of adul- 
teration, but for the purpose of brightening the color of the goods. * * * Intil recent years it was the custom to sell only colored insect powiler, which, of course, requirer the arlition of a eonsiderable percentage of coloring matter. Sone years ago, however, we and some others decided that we would endeavor to educate the trate to accept only a strictly pure inseet powder, uncolored, and we now supply the eolored only, we believe, to one customer, who insists on getting the same.

The particular lot of which you sent us the test, hewever, is not of our own powdering. Last year there was a sudilen and very large advance in the price of insect flowers, and we therefore bought in this country the insect poweler of a brand that has been held to be one of the most reliable and has had an established reputation for over fifty years. The exeedingly small anount of foreign matter added, amounting to a little over 0.5 per cent, proves conclusively that the object was not to adulterate the powder. 



\section{A COMPILATION OF ANALISES OF INSECTICIDES ANI) FUNGICIDES. ${ }^{a}$}

\section{INTRODUCTION.}

In a recent publication ${ }^{b}$ of the Bureau of Chemistry analyses of all the insecticides and fungivides that could be oltained on the American market were given, together with such remarkis concerning their effectiveness as the results seemed to justify. It was originally intended that all of the analyses which had previously been made by the various experiment stations should be included in that bulletin. By reason, howerer, of unaroidable delays, two years passed between the time of collecting the samples and the time of completing the analyses. Since results of this kind. to be of the most ralue, should be published at once, it was thought desirable to reserve the compilation of results obtained in the various States for a future publication. This article therefore includes a compilation of analyses of insecticides and fungicides made by the various experiment stations, together with a few analyses made by the Bureat of Chemistry since the publication of Bulletin 6s.

The insecticides are arranged in groups, as in the previous bulletin, with the addition of two or three classes not taken up in that publication, and the omission of a few classes not examined by the experiment stations. They will he considered in the following order: (1) Paris greens; (2) London purples; (3) insecticides and fungicides, other than Paris greens and London purples, that contain arsenic, copper, or both; (t) soaps; (5) lyes: (6) hellebores: (7) mixtures containing borax: (s) tobacco extracts: (9) formalins: (10) petroleums; (11) miscellaneous solid insecticides and fungicides. and (1:) miscellaneous liquid insecticides and fungicides.

\section{SOURCES OF ANALYSES AND DESCRIPTION OF SAMPLES.}

Table I, on the following pages, is introduced to show the publications from which the analyses were taken and, when possible, the names of the manufacturers of the rarious compounds.

"No responsibility is assumed by the Department for the correctness of compiled analyses, not made within the Department itself.

$b$ U. S. Dept. Agr., Bureau of Chemistry Bul. 6s, The Chemical Composition of Insecticides and Fungicides. 


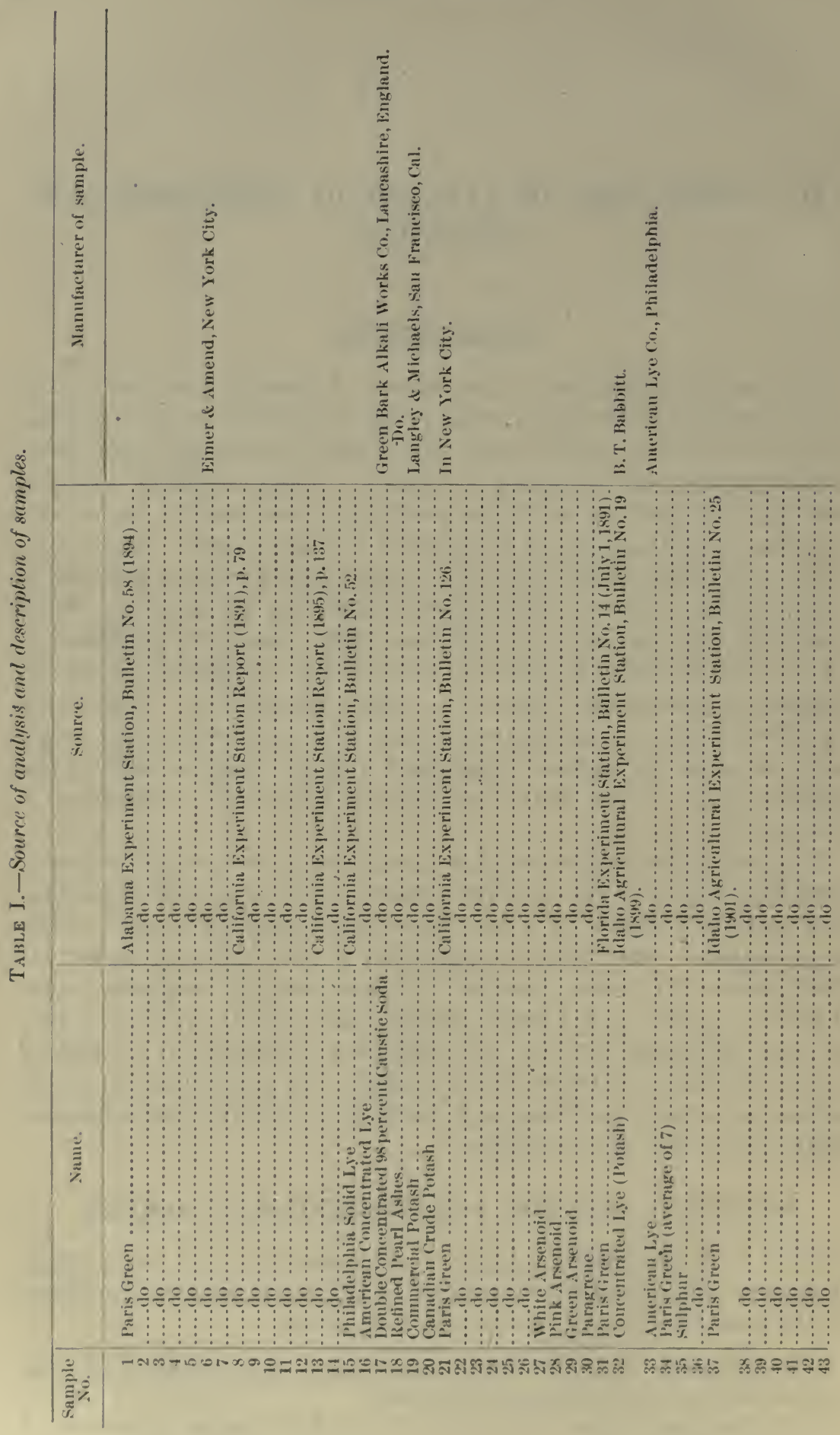



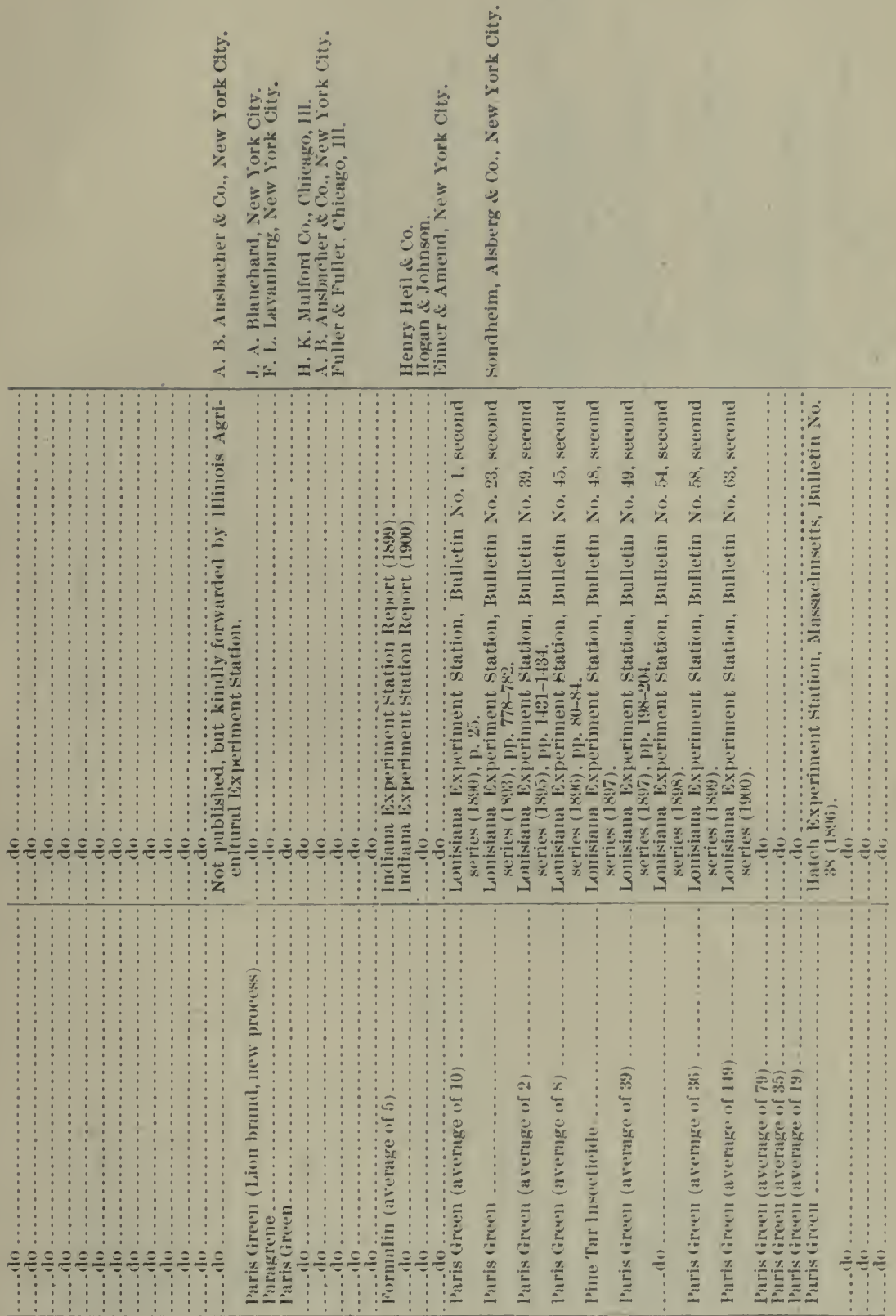


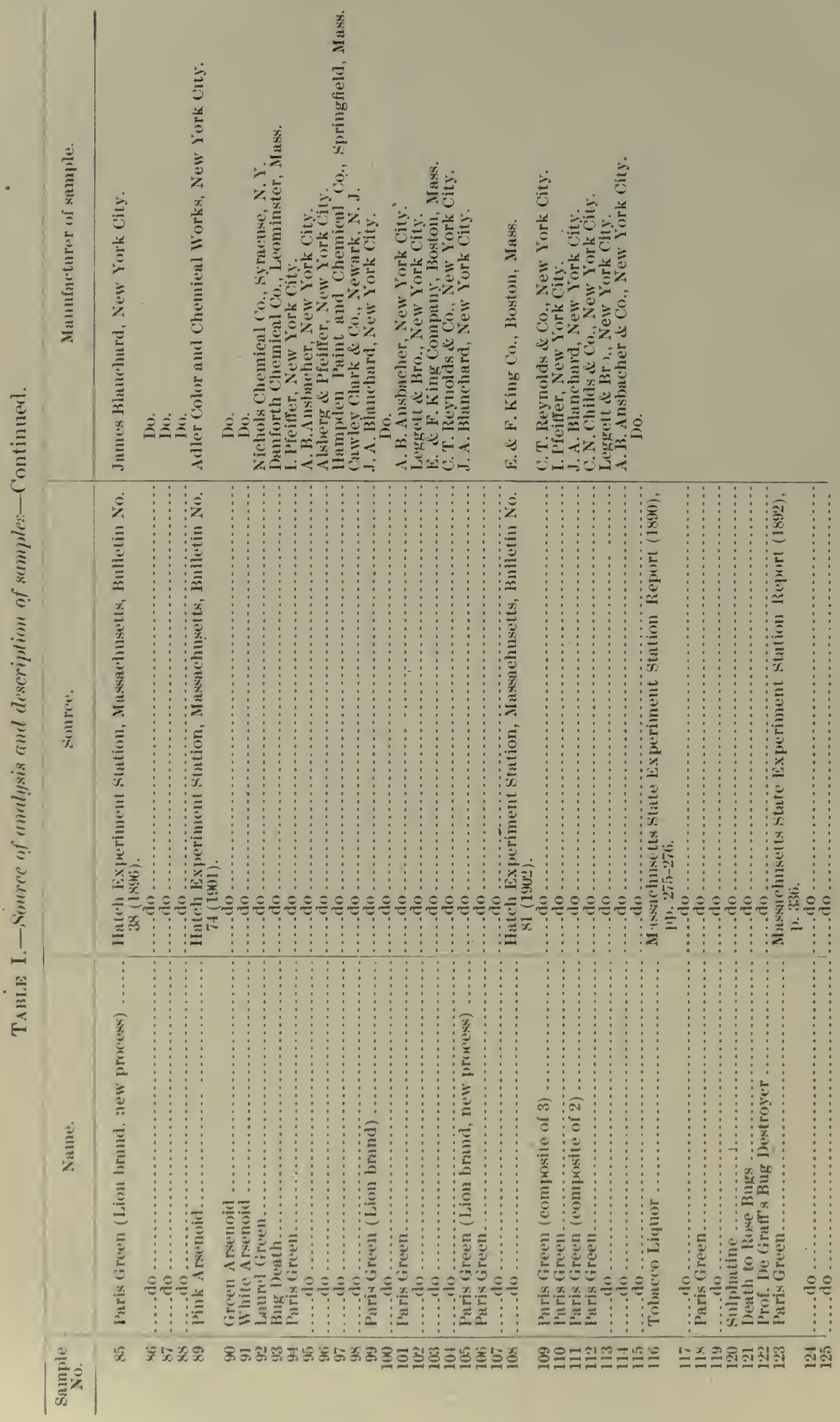



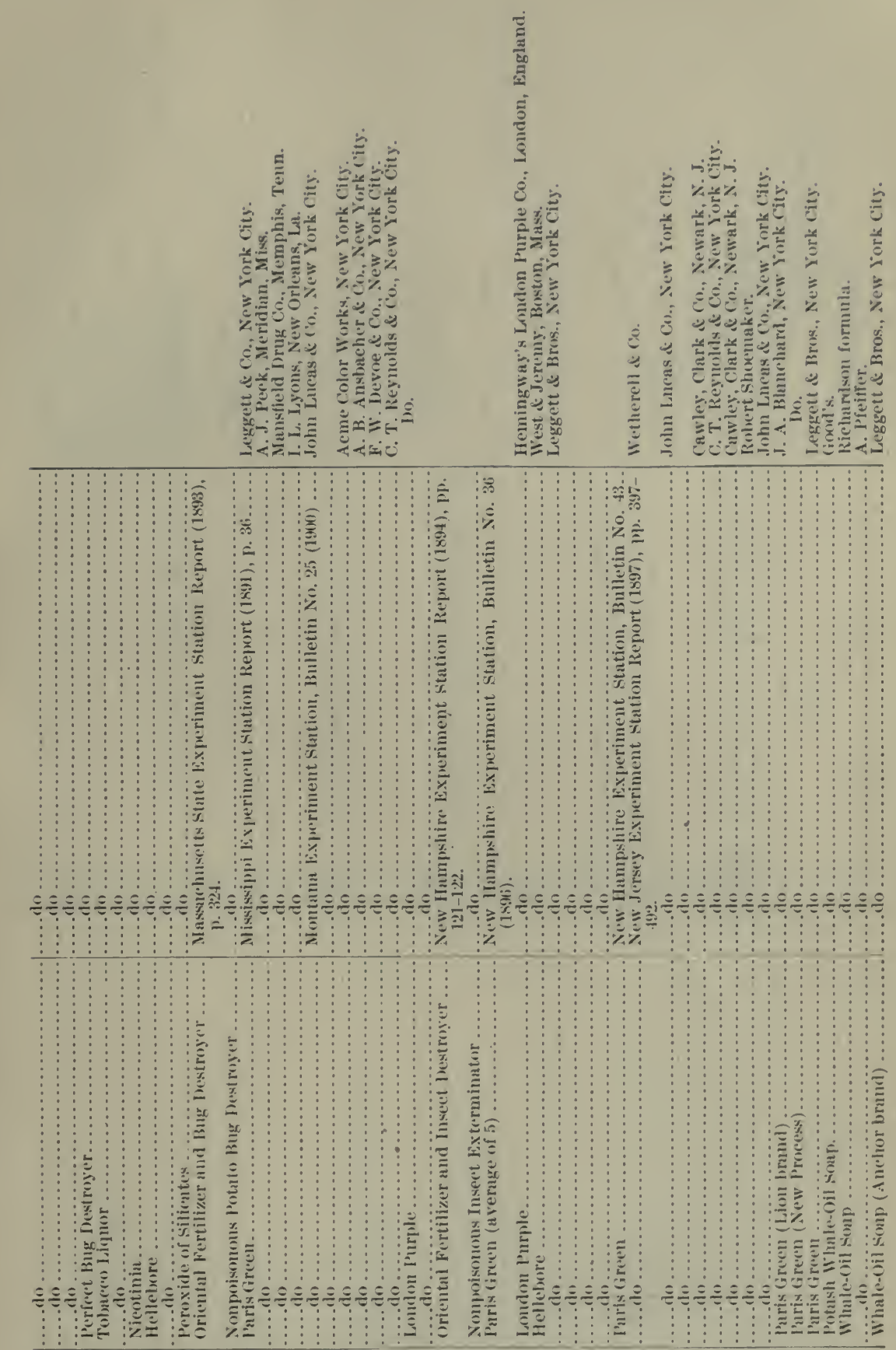

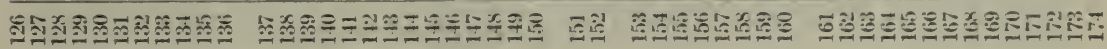




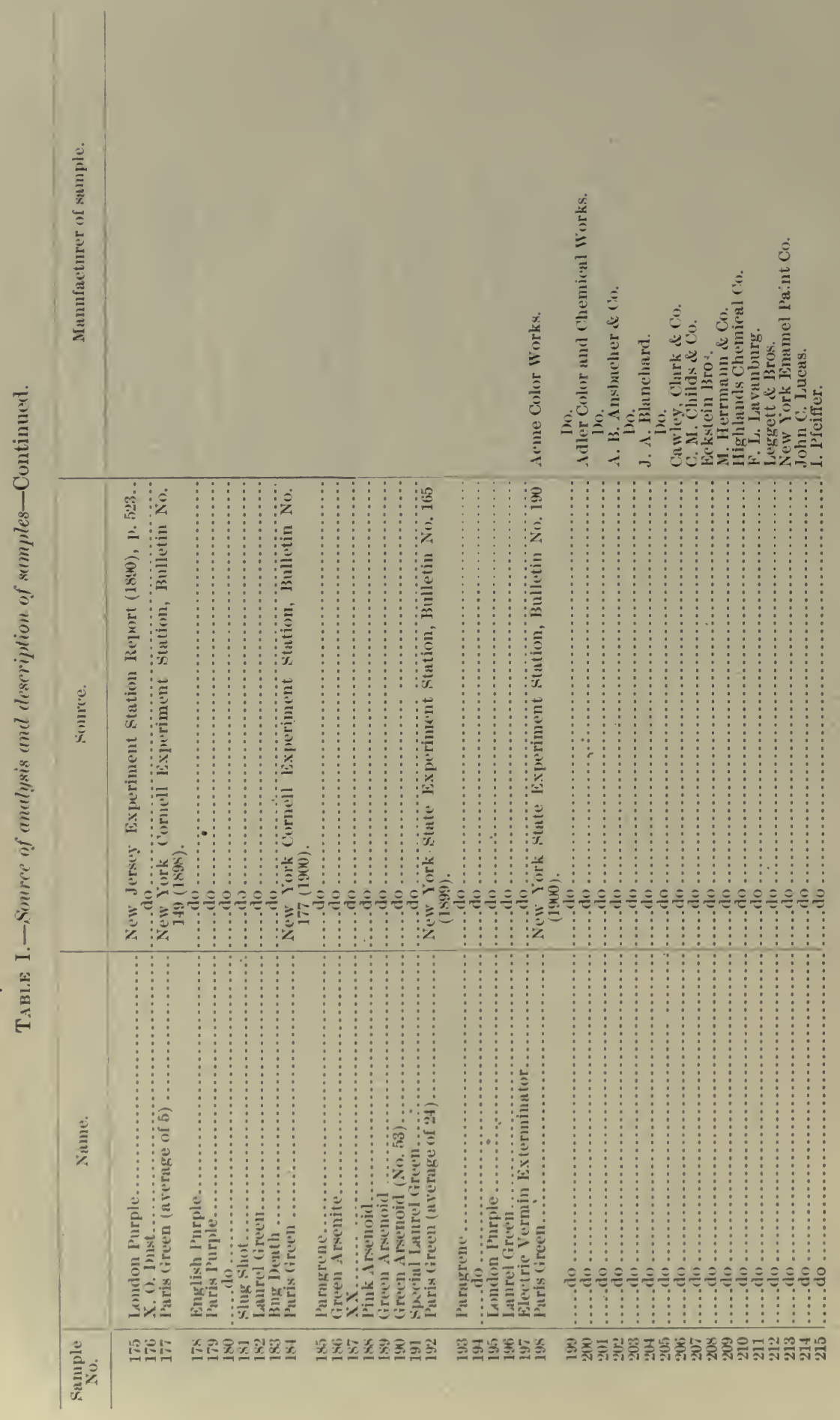



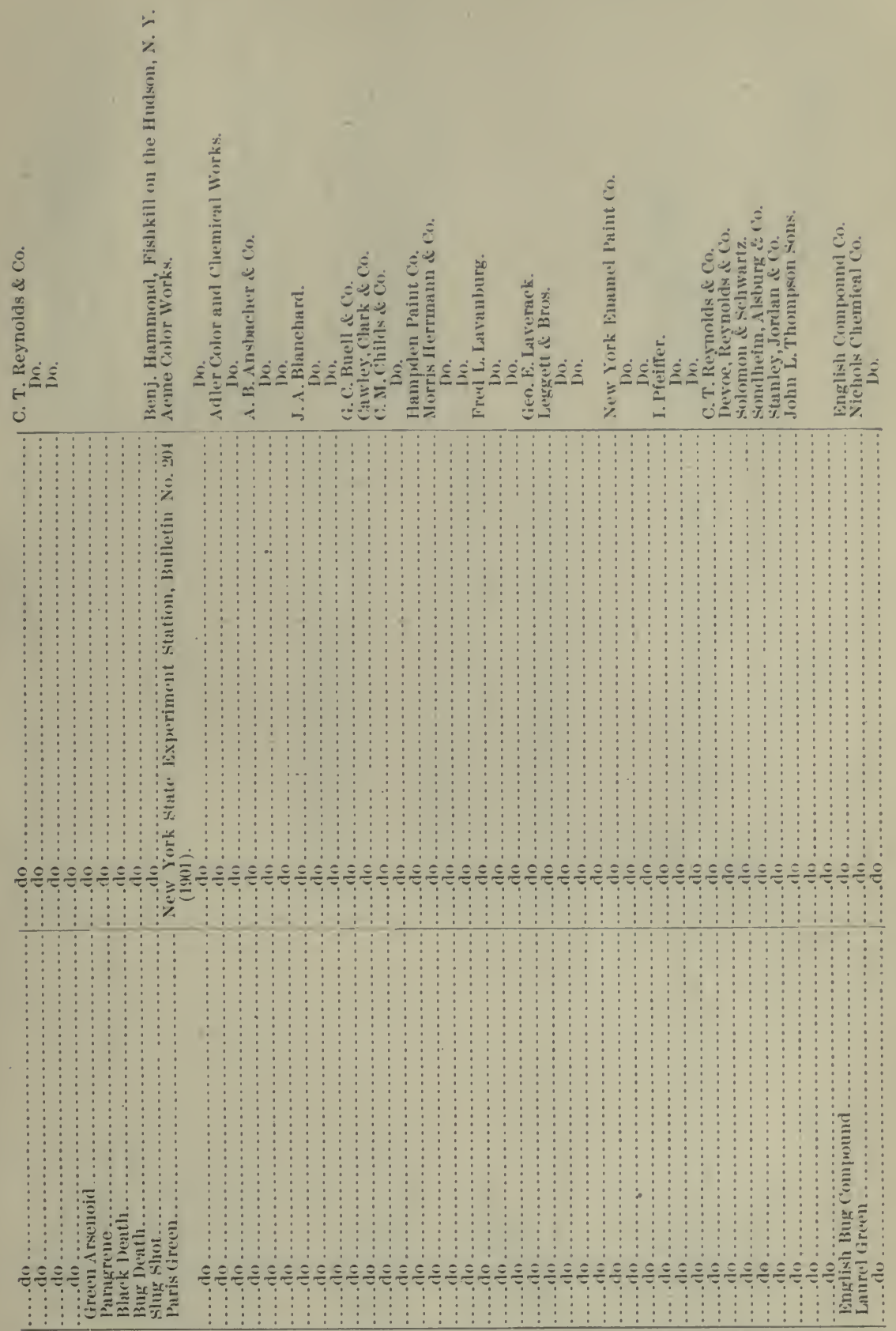

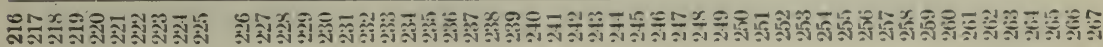




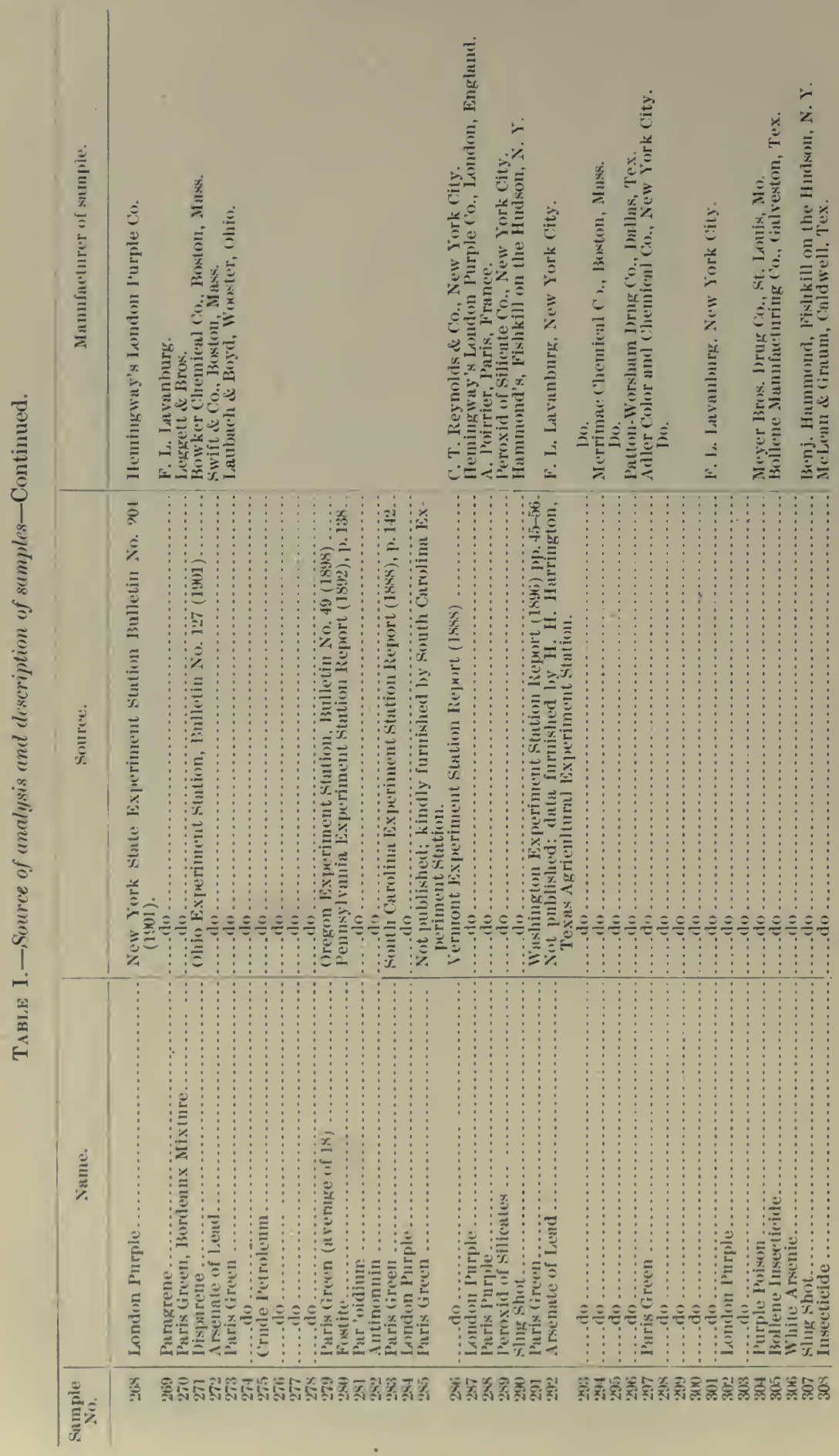




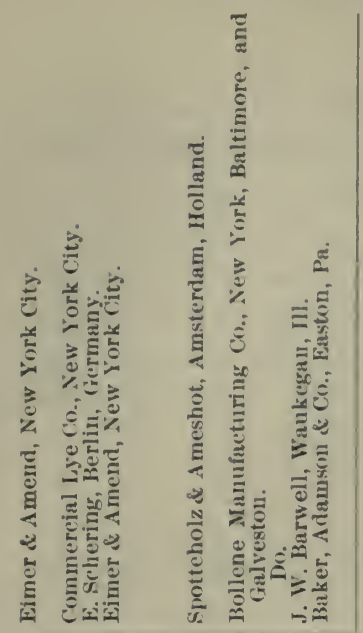

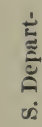

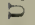

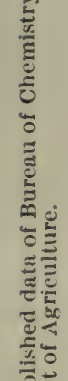

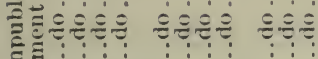

E

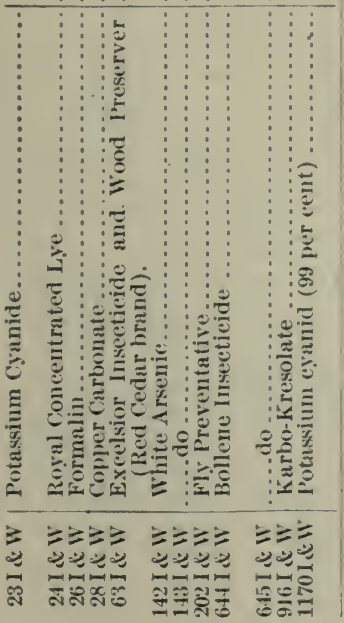


PARIS GREENS.

The analyses of a large number of samples of Paris Green are given in Table II, together with notes that aid in explaining the methods of analysis used. Whenerer the method of analysis was giren in the original publication it is quoted in full. not only in this table, but throughout the hulletin, in order that the reader may judge for himself of its accuracy. In a number of cases in which only one or two constituents were determined in samples of Paris greens the average of all the results is given, mentioning. howerer, the number that fall below the generally accepted standard for such goods.

METHODS.

The method of determining arsenious oxid in samples Nos. 1 to 6. inclusive. was as follows:

Weigh 1 gram of the material into a beaker, ard 30 ('c of strong lydrochloric acid and digest at a temperature below the boiling point, arlding small quantities of $\mathrm{KClO}_{3}$ at frequent intervals. Continue heating until the orlor of chlorin has disappeared, dilute with water, adil ammonia in slight excess, cool, add magnesia mixture drop by drop, stirring vigorously, and let stand twelve hours. Filter, wash with ammonia water, and dry. Detach precipitate from filter and ignite filter, using ammonium nitrate. Transfer the precipitate to a porcelain crucible and heat for a while on an iron plate and finally in the direct flane. Add filter ash and weigh as magnesium priro-arsenate.

In samples Nos. 37 to 55, inclusive (19 samples), the following method was used for determining soluble arsenious oxid:

Allow 0.5 gram of the green to stand in suspension in $50 \mathrm{ce}$ of distilled water in a stoppered cylinder for one week, with occasional shaking, and titrate an aliquot filtered portion of this solution for arsenious oxid.

The method for determining total arsenious oxid in samples Nos. 69 to so, inclusive, was practically the same as that used for samples Nos. 1 to 6 , inclusive.

In determining total arsenious oxid in samples Nos. 195 to 264 , inclusive ( 62 samples), the method given in Bulletin 68 , Bureau of Chemistry. U. S. Department of Agriculture, for the total arsenious oxid in Paris Green was used. In determining copper the electrolytic method was used. In determining soluble arsenious oxid $1 \mathrm{gram}$ was suspended in 1.000 (" of water and allowed to stand orer twentyfour hours in a stoppered flask, with occasional shaking. 'The arsenious oxid groing into solution was titrated with iodin solution.

The soluble arsenious oxid in sample No. 285 was determined by extracting $1 \mathrm{gram}$ of Paris Green with $400 \mathrm{cc}$ of water for nine days, with occasional shaking. and titrating the arsenious oxid in an aliquot portion of the resulting solution with iodin. 
ANALYSES OF INSECTICIDES AND FUNGICIDES.

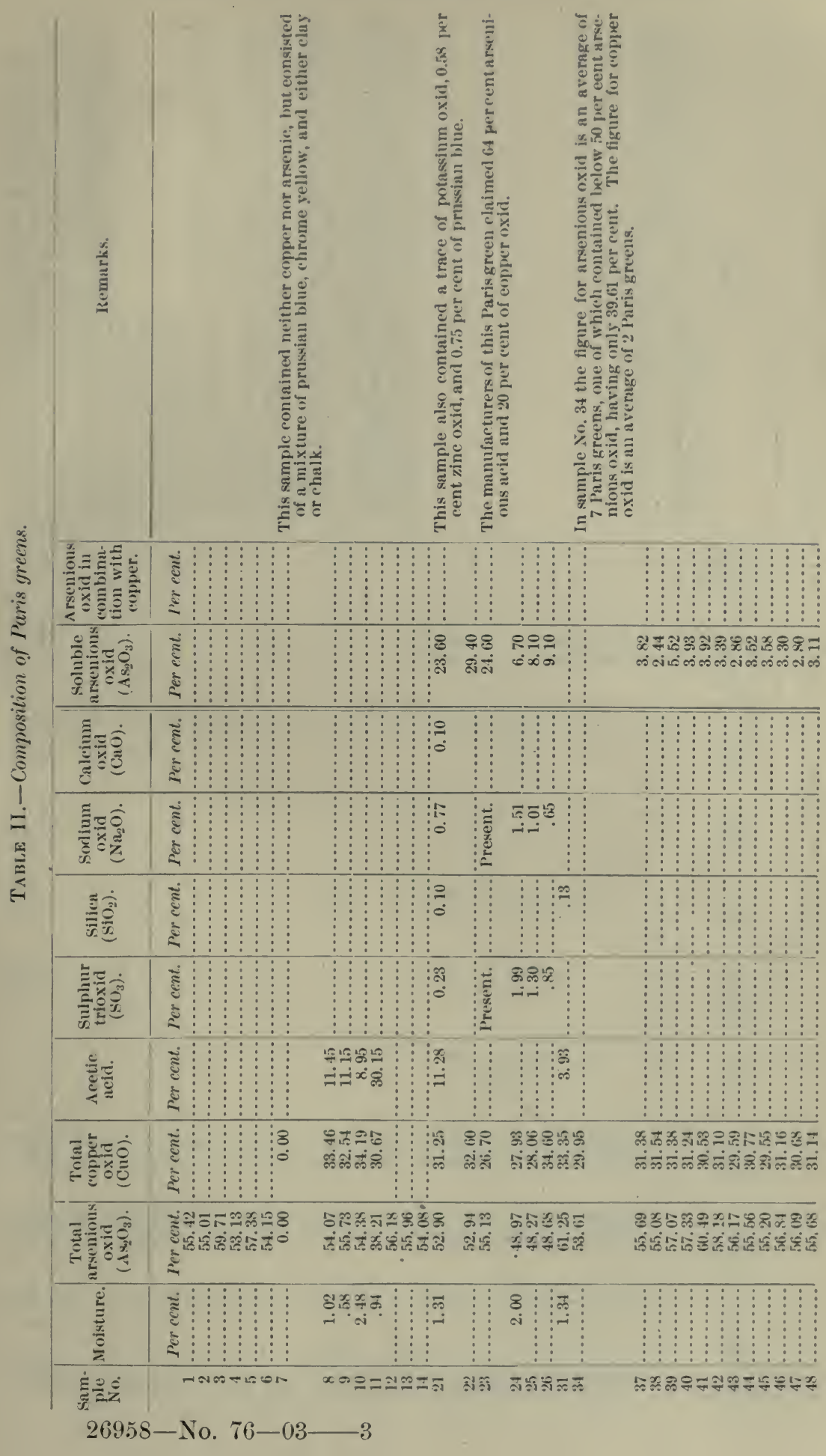




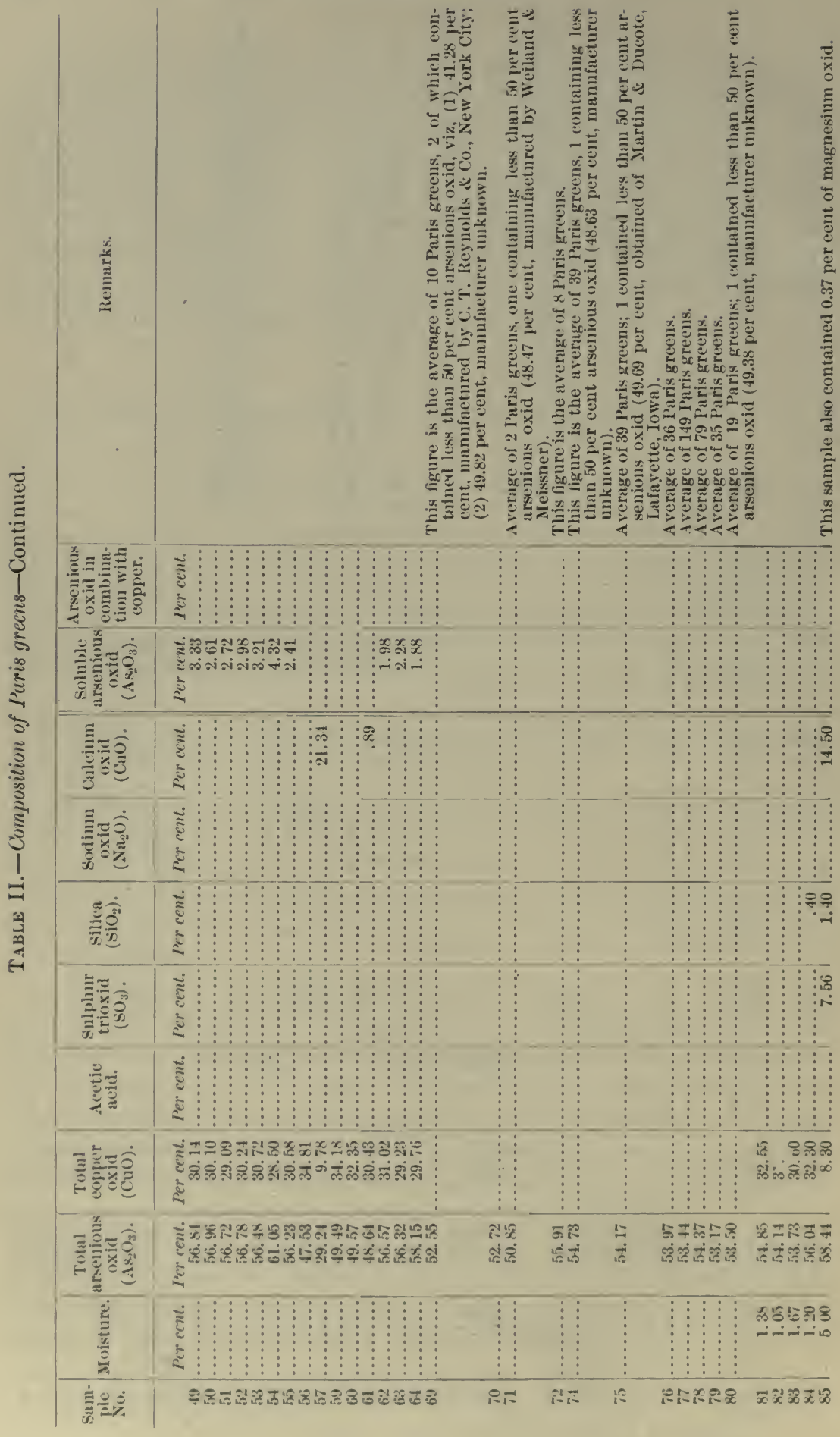




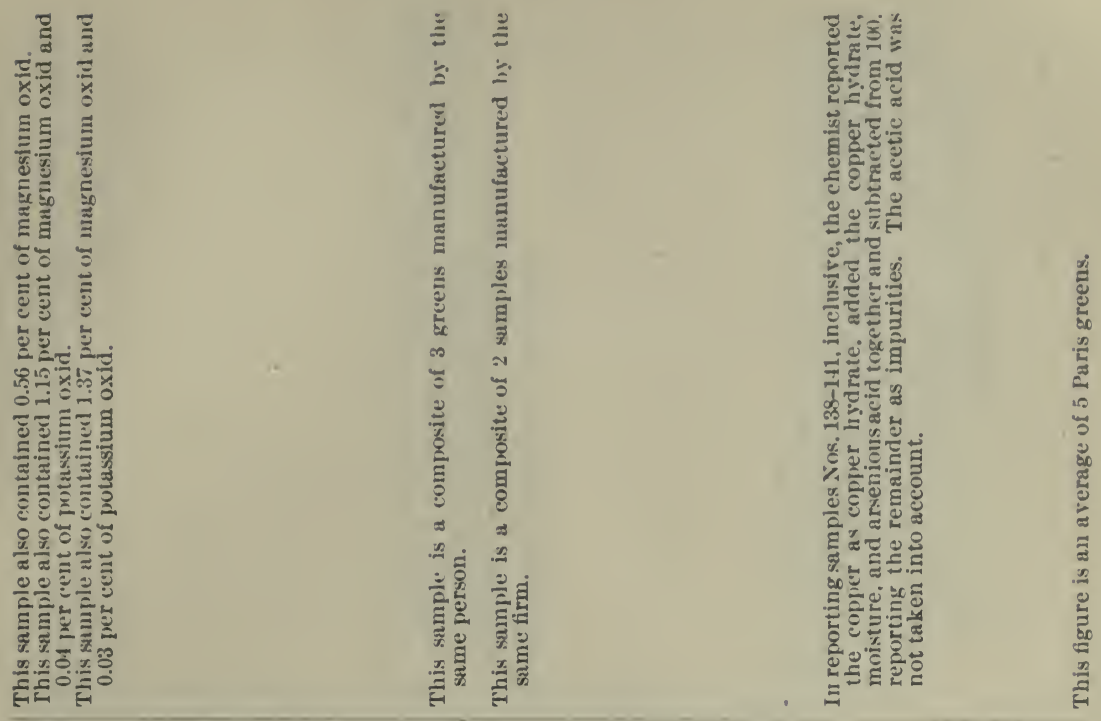

我施

$\stackrel{200}{\Xi}$

\begin{tabular}{l}
\hline \multirow{2}{*}{$=0$} \\
$\vdots$
\end{tabular}

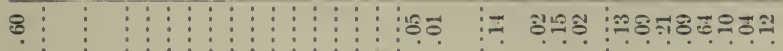

$8 \div$

อิt:

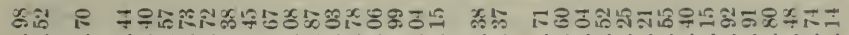

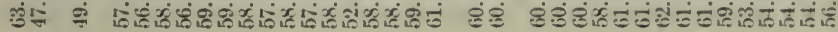

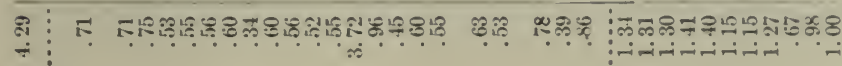

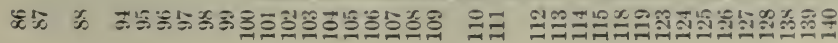

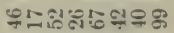

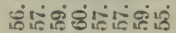

5

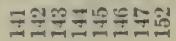




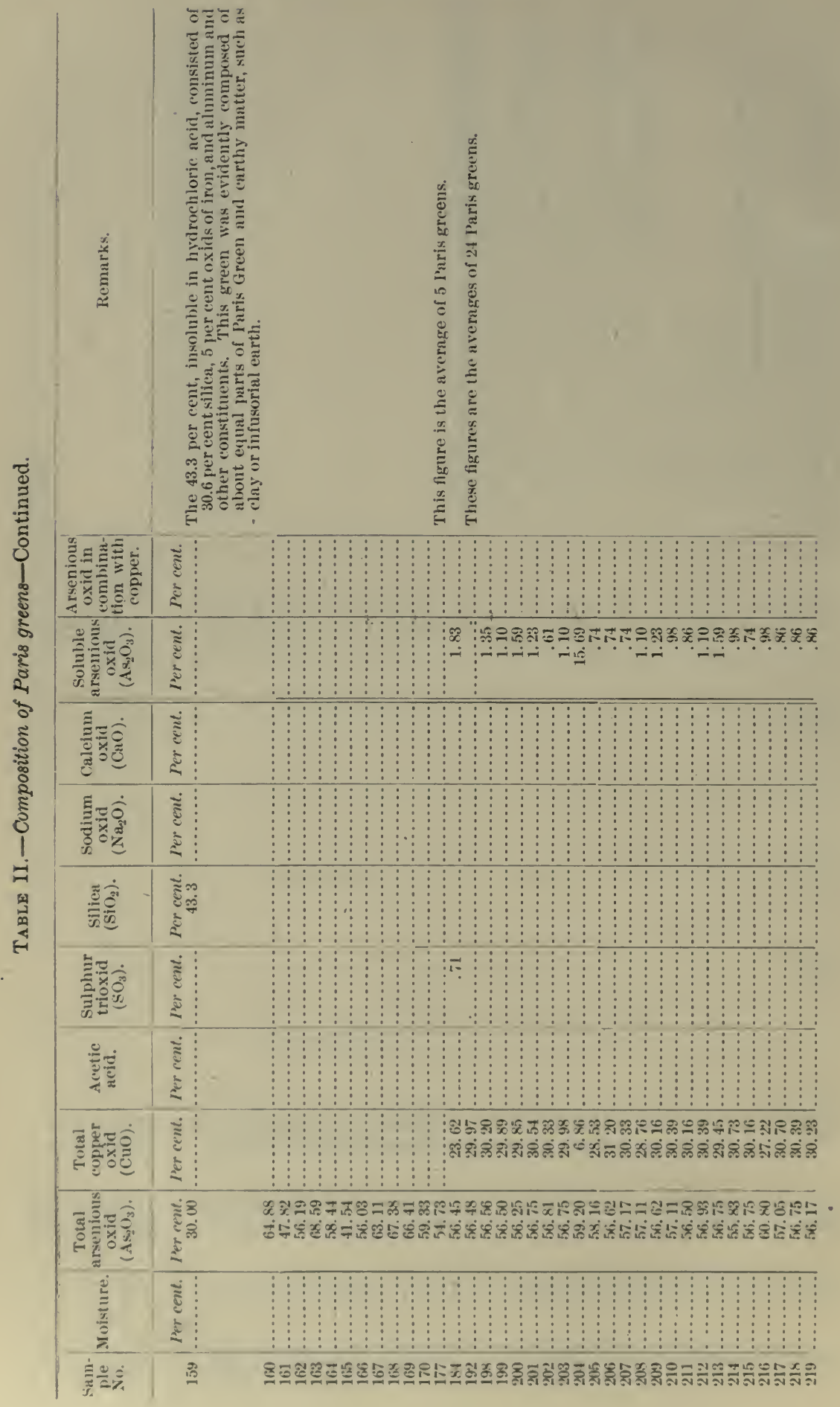




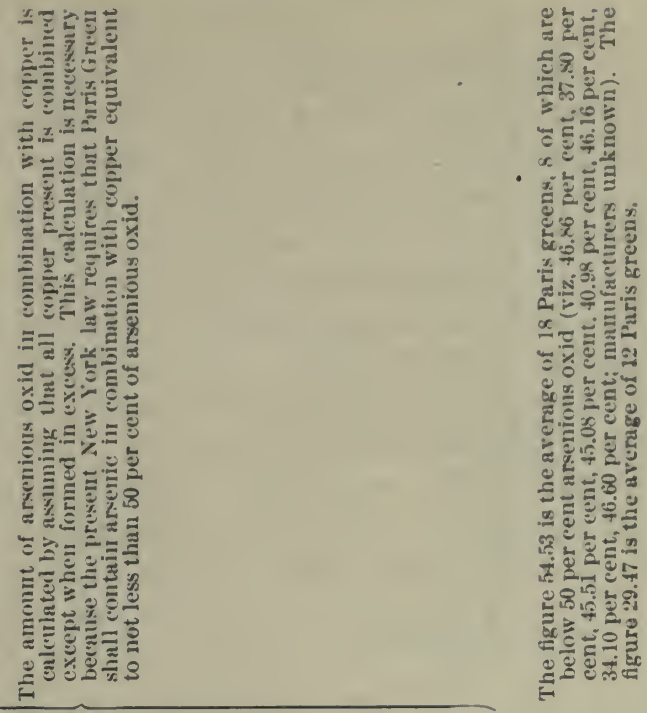

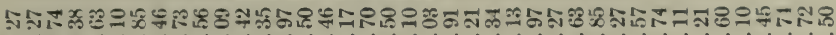

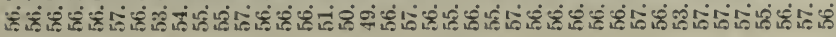

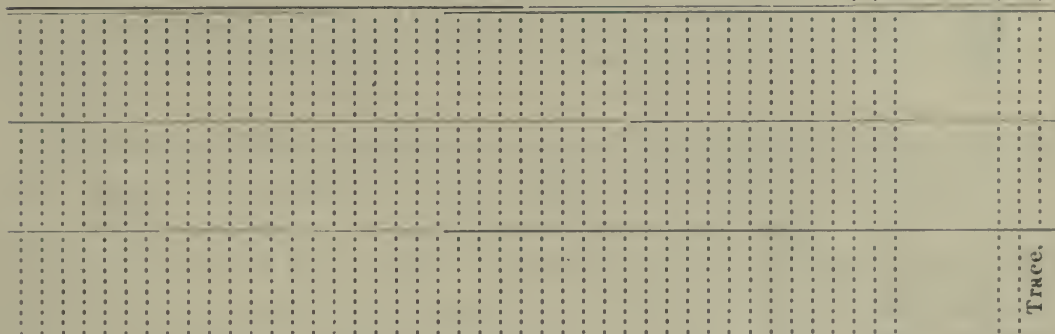




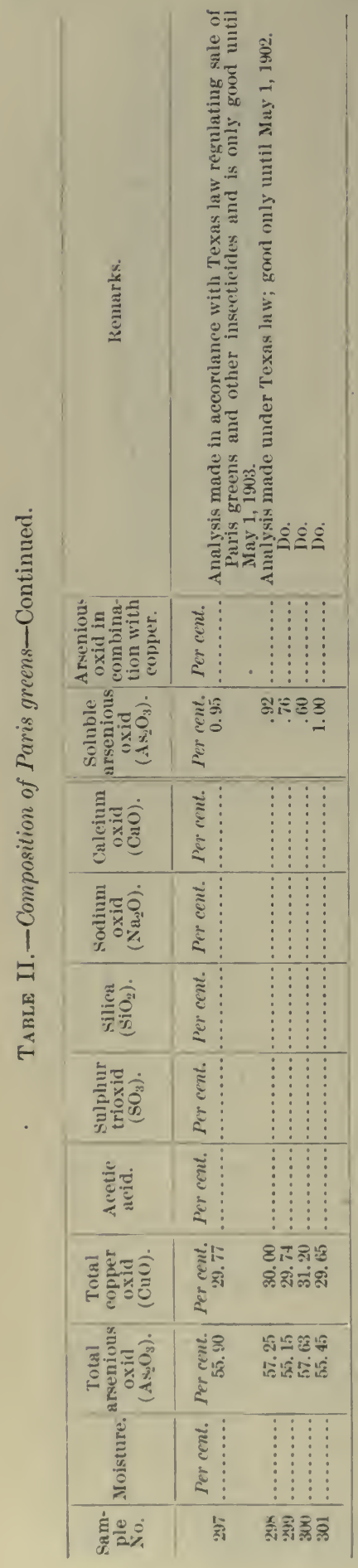


A glance at Table II at once makes it apparent that only 1 sample out of more than 650 examined contains neither copper, acetic acid, nor arsenious oxid-this is sample No. 7. One other sample, No. 159, consists of about equal parts Paris Green and some insoluble material that appears to be clay or infusorial earth. Out of the total number examined 31 contained less than 50 per cent arsenious oxid. It will be noted, however, that a number of these samples said to contain less than 50 per cent arsenious oxid were analyzed by a method (the magnesium pyro-arsenate method) that has since been shown to give results about 1 per cent low. If a more accurate method of analysis had been used, the number falling below 50 per cent arsenious oxid would very likely be materially diminished. It also appears that the Western States receive more of those samples that contain small percentages of arsenious oxid than do the Northern States.

The State of Louisiana, which prerious to 1899 occasionally received samples containing small percentages of arsenious oxid, does not seem to have had any upon the market during 1899 and 1900). Out of 96 samples of Paris Green examined in New York State during the years 1899 to 1901 , inclusive, none was found that contained less than 50 per cent arsenious oxid. In both California and Oregon, until a very recent date, quite a large amount of the Paris Green on the market contained small percentages of arsenious oxid, although it is said that this condition has been very much improved during the last two years.

Concerning soluble arsenious oxid in Paris greens, it appears that those upon the market in California until recently contained very large quantities, those in Idaho were very fair, only 2 out of 19 containing more than $t$ per cent, those in Illinois, Montana, and Texas contained very small percentages, and those in New York the same, only 1 out of 90 containing more than 4 per cent. This one was sample No. 204, containing 15.69 per cent of free arsenious oxid.

It must be borne in mind, howerer, in looking over the figures for free arsenious oxid that the results in one State can not be compared with those in another, since the methods of analysis were rery likely different in every case and would lead to entirely different results. It may be of interest to those who have not read the previous bulletin of the Bureau of Chemistry on this subject,to mention that out of the 45 samples of Paris Green, from all parts of the United States, which were examined 71 per cent contained more than 4 per cent of soluble arsenious oxid and 16 per cent contained more than 6 per cent of arsenious oxid when a ten-day extraction of 1 gram with 1,000 cc of water was made. In view of the facts brought out in that bulletin, a 6 per cent, rather than a 4 per cent, limit for soluble arsenious oxid was adrocated when the above method of analysis was employed. 
From the figures given above, together with information received from the various States, it appears that upon the whole the purity of the Paris greens upon the American market is steadily and rapidly upon the increase.

\section{LONDON, ENGLISH, AND PARIS PURPLES.}

The analyses of 10 samples of London Purple, 1 sample of English Purple, and 3 samples of Paris Purple are given in the following table (III). All of these are products obtained by boiling a waste product from the analine-dye industry with lime. Since it was not known at the time these analyses were made that the arsenic was present, both as arsenious and arsenic acids, the total arsenic was determined and reported as arsenious oxid, only the soluble arsenious oxid being determined, instead of both soluble arsenic and arsenious oxids.

TABLE III.-Composition of London purples and closely allied mixtures.

\begin{tabular}{|c|c|c|c|c|c|c|c|c|}
\hline $\begin{array}{l}\text { Saml- } \\
\text { ple } \\
\text { No. }\end{array}$ & Same. & Moisture. & $\begin{array}{l}\text { Arselli- } \\
\text { ous oxid } \\
\left(\mathrm{As}, \mathrm{O}_{3}\right) \text {. }\end{array}$ & $\begin{array}{c}\text { Calcium } \\
\text { oxid } \\
\text { (CaO). }\end{array}$ & \begin{tabular}{|} 
Ferric \\
oxid and \\
alumina \\
$\left(\mathrm{Fe}_{2} \mathrm{O}_{3}\right.$ \\
and \\
$\left.\mathrm{Al}_{2} \mathrm{O}_{3}\right)$
\end{tabular} & $\begin{array}{c}\text { Sulphur } \\
\text { trioxid } \\
\left(\mathrm{SO}_{3}\right) .\end{array}$ & Dse. & $\begin{array}{c}\text { Soluble } \\
\text { arsenious } \\
\text { oxid } \\
\left(\mathrm{A}_{2} \mathrm{O}_{3}\right)\end{array}$ \\
\hline $\begin{array}{l}148 \\
149\end{array}$ & $\begin{array}{l}\text { London Purple } \\
\ldots . . \text { do........... }\end{array}$ & $\begin{array}{l}\text { Per cent. } \\
\text {............ }\end{array}$ & $\begin{array}{r}\text { Per cent. } \\
51.43 \\
37.18\end{array}$ & $\begin{array}{c}\text { Per cent. } \\
0\end{array}$ & Per cent. & $\begin{array}{c}\text { Per cent. } \\
\text {........... }\end{array}$ & $\begin{array}{c}\text { Per cent. } \\
\cdots \cdots \\
\cdots\end{array}$ & $\begin{array}{r}\text { Per cent. } \\
0.54 \\
2.58\end{array}$ \\
\hline $\begin{array}{l}153 \\
175\end{array}$ & & 3.27 & $\begin{array}{l}37.56 \\
41.44\end{array}$ & 24.32 & 3.37 & 0.31 & 27.29 & (i) \\
\hline 19.5 & & ........... & 32.88 & ........... & ........... & ... & ...... & \\
\hline 268 & do & 3.99 & 32. & & & & ..... & 12.21 \\
\hline $\begin{array}{l}254 \\
287\end{array}$ & $\because$ & $\begin{array}{l}3.99 \\
3.37\end{array}$ & $\begin{array}{l}42.60 \\
46.73\end{array}$ & 24.35 & 1.31 & $\dddot{b .} 46$ & & …m. \\
\hline 302 & $\ldots$ & ... & 31.90 & $c 25.78$ & .... & & $\cdots$ & 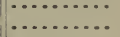 \\
\hline 303 & $\ldots . . d$ & & 31.50 & $d 25.00$ & ... & & & \\
\hline $\begin{array}{l}178 \\
179\end{array}$ & English Pur & $\cdots$ & $\begin{array}{l}36.75 \\
47.05\end{array}$ & ..... & & & & $\begin{array}{r}5.8 \\
11.8\end{array}$ \\
\hline 180 & 1... do................... & & & & & & & 13.88 \\
\hline 288 & .....do.................... & 6.05 & 33.72 & 4.55 & 4.76 & e. 91 & & \\
\hline
\end{tabular}

a A portion digested 40 hours with water at room temperature gave 8.11 per cent arsenious oxid and 2.8 .5 per cent soluble ealcium oxid. A portion digested with hot water until all the soluble arsenious oxid had dissolved gave 16.45 per cent soluble arsenious oxid and 3.26 per cent soluble culcium oxid.

$b$ Also contains 1.65 per cent nitrogen.

$c$ This analysis was made in accordance with the Texas law regulating the sale of Paris Green and other insecticides and is good only until May $1,1903$.

d Made in accordance with Texas law, but good only until May 1, 1902.

e Also contained 2.8 per cent nitrogen and 0.57 per cent potassium oxid.

It will at once be noted that the rariation in the amount of arsenic in different samples of London Purple and Paris Purple is very large. In the case of 11 samples examined more recently in this Bureau (published in Bulletin (68) this variation in the arsenic content is not nearly so great. It would, therefore, appear that the amount of this constituent in such goods is becoming more constant in the more recently manufactured samples.

The figures for soluble arsenious oxid can not be compared with those obtained more recently in this laboratory, since the soluble arsenic oxid was not determined in the earlier analyses, and it is only w'en both figures are at hand that any conclusions of a positive nature can be drawn. 
IXSECTICIDES ANI) FUNGICIIES, OTHEIR THAN IALIS GRELX ANI) IONDON

PLLPLE. THAT CONTAIN ARSENIC, CORPEL, OL BOTH. AS THLIR ACTIVl: CONSTITUENTS.

In Table IV is given a compilation of analyses of Green Arsenoid, Green Arsenite, Paragrene, Laurel Green, and White A rsenic, together with two analyses of White Arsenic made in this laboratory.

TABLE IV.-Compesition of Green Arsenoid, Green Arsenite, I'urugrme, Laurel Cirepn, and White drsenic.

\begin{tabular}{|c|c|c|c|c|c|c|c|}
\hline Sample No. & Name. & Mointure. & $\mid \begin{array}{c}\text { Total } \\
\text { arsenfous } \\
\text { oxid } \\
\left(\mathrm{A} \leqslant \mathrm{O}_{3}\right)\end{array}$ & $\begin{array}{c}\text { Copper } \\
\text { oxirl } \\
\text { (CuO). }\end{array}$ & $\begin{array}{c}\text { Caleium } \\
\text { oxicl } \\
\text { (CaO). }\end{array}$ & $\begin{array}{l}\text { Sulphur } \\
\text { trioxid } \\
\left(\mathrm{SO}_{3}\right) .\end{array}$ & $\begin{array}{c}\text { Soluble } \\
\text { a rsenious } \\
\text { oxid } \\
\text { (Ax.O.). }\end{array}$ \\
\hline$a$ & Green Arsenoid. & $\begin{array}{r}\text { Per cent. } \\
2.77\end{array}$ & $\begin{array}{r}\text { Per cent. } \\
61.43\end{array}$ & $\begin{array}{r}\text { Ier crent. } \\
28 . \times 3\end{array}$ & $\begin{array}{l}\text { I'er cent. } \\
. . . .\end{array}$ & $\begin{array}{c}\text { Irer cent. } \\
\ldots \ldots\end{array}$ & $\begin{array}{r}\text { Per cent. } \\
7.82\end{array}$ \\
\hline & ..... do .......... & 1.44 & 50.77 & 31.90 & & & \\
\hline 0 & ..... do & 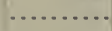 & 60.63 & 29.29 & & 1.55 & 3.53 \\
\hline 0 & .....do. [No.53] & & 53.71 & 29. & & 3.7 & 8.33 \\
\hline & Gr..do & 1.9 & 5 & & & & 2. \\
\hline & grene & (6. 20 & $\begin{array}{l}5 \\
40\end{array}$ & $\begin{array}{l}31 . \\
23 .\end{array}$ & & & 23. \\
\hline & ..... do .. & & 19 & 19. & 13.31 & & \\
\hline & .... do. & & 55 & 27 & & 1.34 & 3.21 \\
\hline & 0 & & $\frac{4}{5}$ & 18 & & 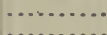 & . \\
\hline & do & 8.15 & 36. & 17. & 14.20 & & 1. \\
\hline & el Gre & 7.64 & 7. & 13. & 26.31 & & \\
\hline & & & & 12.52 & & & \\
\hline & $\mathrm{l} \mathrm{Gr}$ & & 42. & & 35. 39 & & 1.15 \\
\hline & Laurel Gre & & & 11. & $\cdots$ & & \\
\hline $\begin{array}{l}266^{\circ} \\
267\end{array}$ & ..... do $\ldots .$. & & $\begin{array}{l}4.85 \\
5.45\end{array}$ & $\begin{array}{l}12.68 \\
12.05\end{array}$ & $\cdots \cdot$ & & .0 \\
\hline 300 & White Ars & & 98.00 & & & & \\
\hline 142 & .....do .... & & 99.86 & & & & \\
\hline & & & 99.99 & & & & \\
\hline
\end{tabular}

a The following constituents were also present: Siliea, $0 . i 0$ per cent; organic matter, 6.67 per cent. $b$ In sample No. 30 the following constituents were also present: Acetic acid, 6.72 per cent; ('ulcium sulphate, 19.31 per cent; sodium sulphate, 2.26 per cent; sodium ehlorid, 0.25 per eent; ferrie oxid, 0.20 per cent.

$c$ Large amounts of calcium earbonaie and hydrate were also present.

- dThis analysis was made in accordance with the Texas law regulating the sale of Paris Grecn and other insecticides and is good only until May 1, 1902.

$e$ The method of analysis used is that described for total arsenious oxid in Paris Green in Bulletin 68 of this Bureau.

The figures obtained by different analysts for Green Arsenoid, Paragrene, and Laurel Green show that the composition of these substances is very variable, especially as to the content of arsenious oxid, which varies in the first case from 50.77 per cent to 61.43 per cent, in the second from 19.31 per cent to 55.57 per cent, and in the third from 3.83 per cent to 42.69 per cent. The figures obtained for soluble arsenious oxid, here as elsewhere in this compilation, can not be compared, since the methorls of extraction were very likely different.

The two samples of White Arsenic analyzed in this laboratory were received from Boise City, Idaho, by the Division of Entomology. They are both evidently of exceptional purity and will give good results when used for preparing Calcium Arsenite, the purpose for which they were purchased. 
WIITE ARSENOIIS.

TABle: V.-Composition of Ihite Arsenoids.

\begin{tabular}{|c|c|c|}
\hline Constituents. & $\begin{array}{l}\text { Sample } \\
\text { No. } 27 \text {. }\end{array}$ & $\begin{array}{l}\text { Sample } \\
\text { No. } 91 \text {. }\end{array}$ \\
\hline 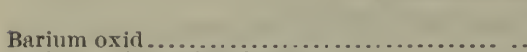 & $\begin{array}{r}\text { Per cent. } \\
4: .39\end{array}$ & $\begin{array}{r}\text { Per cent. } \\
41.43\end{array}$ \\
\hline Barium to join with chlorin.. & 8.60 & 6.16 \\
\hline Lead oxid ........................ & 1.55 & .96 \\
\hline 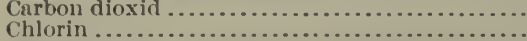 & 10.15 & 8.92 \\
\hline 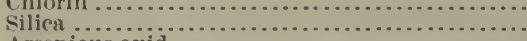 & $\begin{array}{r}4.45 \\
.20\end{array}$ & $\begin{array}{l}3.19 \\
\ldots . .\end{array}$ \\
\hline Arsenious oxid $\ldots \ldots \ldots \ldots \ldots \ldots \ldots . . . . . . . .$. & 27.64 & 31.90 \\
\hline Moisture .................. & 4.00 & 2.35 \\
\hline Solub'e ursenious oxid.. & 27.64 & \\
\hline
\end{tabular}

P.ARIS (IREEN AXI) BORDEAUX MIXTER.

The composition of this simple, No. 270 , was as follows:

Per cent.

Total arsenious oxid ............................... 15. 49

Copper oxid ........................................ 16. 02

Soluble arsenious oxid ............................ 1.

SLI'G SHOTS.

TABLE VI.-Composition of Slug Shots.

\begin{tabular}{|c|c|c|c|}
\hline Constituents. & $\begin{array}{l}\text { Sample } \\
\text { No. 181. }\end{array}$ & $\begin{array}{l}\text { Sample } \\
\text { No. } 290 .\end{array}$ & $\begin{array}{l}\text { Sample } \\
\text { No. } 307 .\end{array}$ \\
\hline Arsenious oxid.. & $\begin{array}{r}\text { Per cent. } \\
0.60\end{array}$ & $\begin{array}{r}\text { Per cent. } \\
1.58\end{array}$ & $\begin{array}{l}\text { Per cent. } \\
\text {........... }\end{array}$ \\
\hline Copper oxid .... & 1.44 & $\begin{array}{r}1.00 \\
.60\end{array}$ & an........... \\
\hline Lime .............. & $\ldots \ldots$ & 30.25 & 28.82 \\
\hline $\begin{array}{l}\text { Sulphur trioxid } \ldots \ldots \ldots \ldots . . . . . \\
\text { Ferric oxid and alumina........ }\end{array}$ & ........ & 43.02 & 41.18 \\
\hline 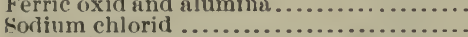 & (n......... & $\begin{array}{r}.79 \\
2.83\end{array}$ & (n......... \\
\hline Insoluble............................ & $\ldots \ldots$ & $\begin{array}{l}2.83 \\
1.38\end{array}$ & (n.......... \\
\hline Volatile organic matter (by differe & & 4. 79 & \\
\hline
\end{tabular}

The sodium chlorid in sample No. 290 was calculated from a content of 1.72 per' cent of chlorin. 'The volatile organic matter in this sample consisted principally of dead oil.

In sample No. 307 small amounts of sulphur, copper sulphate, oxid of iron, carbolic acid, and tobacco, with less than 1 per cent of arsenic, were also present.

Slug Shot is evidently a mixture of fairly constant composition containing in all eases small amounts of arsenious oxid and copper oxid as active poisonous constituents.

PEROXII) OF SILICATES.

TABLE VII.-C'omposition of peroxid of silicates.

\begin{tabular}{|c|c|c|}
\hline (imstituents. & $\begin{array}{l}\text { Sample } \\
\text { No. } 135 .\end{array}$ & $\begin{array}{l}\text { Sumple } \\
\text { No. } 249 .\end{array}$ \\
\hline Moisture ... & $\begin{array}{r}\text { Per cent. } \\
1.65\end{array}$ & Per cent. \\
\hline Arsenious oxid. & -.57 & 1.47 \\
\hline Coppler oxid.... & .33 & .28 \\
\hline Sulphur trioxid & $\begin{array}{l}49.66 \\
41.18\end{array}$ & 52. 29 \\
\hline 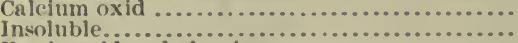 & $\begin{array}{r}41.18 \\
2.31\end{array}$ & $\begin{array}{r}36.43 \\
1.93\end{array}$ \\
\hline 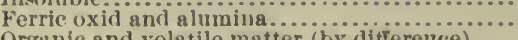 & & 1.40 \\
\hline Organic and volatile matter (by difference)... & .......... & 4.76 \\
\hline
\end{tabular}


This mixture evidently contains arsenious oxid and copper as the active constituents, diluted with a large amount of gypsub. In so far as the arsenious oxid and copper content are concerned, this mixture is of value as an insecticide; but the grpsum is inert in its action upon insects, except that when the spiracles are not well protected they may be closed up with this or any other fine dust.

\section{BLACK IDEATII.}

Compresition of Blark Ineth.

$$
\text { [No. 222.] }
$$

Moisture . . . . . . . . . . . . .

Sulphate of lime (gypsum) .......................... 45. 34

Magnesium oxid ................................... 3.98

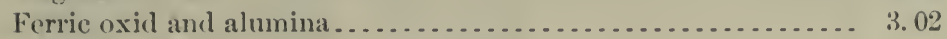

Arsenious oxid........................................ . 79

Copper oxid ...................................... . 41

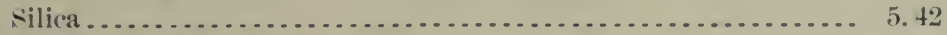

Loss on ignition . . . . . . . . . . . . . . . . . . . . . . . . . . . 28.91

EN(ILISH BLG ('OMPOENI).

The composition of this compound, No. 265, is as follows:

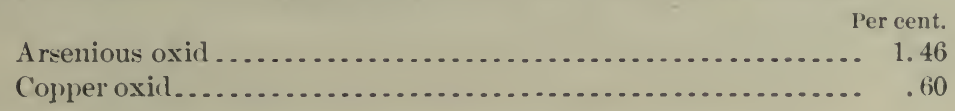

ORIENTAL FERTILIZER AND BLG IOESTIROYER.

[No. 136.]

Composition of Oriental Fertilizer and Bug Destroyer.

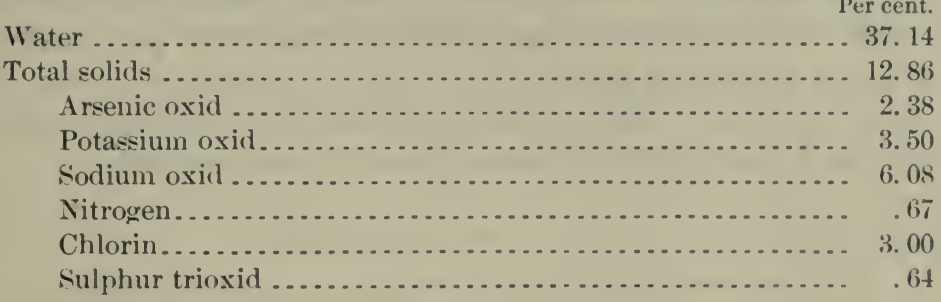

This mixture is evidently sodium and potassium arsenates dissolved in water. In so far as its content of arsenic is concerned, it would be of value in killing insects. It might, however, if sprayed upon trees, cause some damage by scorching, as the arsenic is in a soluble conditıon. Its fertilizing value is shown by its content of potash and nitrogen.

Another sample of Oriental Fertilizer and Bug Destroyer, No. 150, gave, in 1,000 ce of liquid, 13.12 grams of arsenic and 10.28 grams of potassium oxid. 
LEAD ARSEXATE AND PINK IRSENOID.

The analyses of samples of Lead Arsenate and Pink Arsenoid, or Lead Arsenite, are given in the following table:

T.1BLe VIII.-Composition of Learl Arsena'e and Pink Arsenoid.

\begin{tabular}{|c|c|c|c|c|c|c|}
\hline $\begin{array}{c}\text { Sumple } \\
\text { Ň.). }\end{array}$ & Name. & Moisture. & $\begin{array}{c}\text { Lead } \\
\text { oxicl } \\
\text { (PbO). }\end{array}$ & $\begin{array}{c}\text { Ar:enic } \\
\text { oxid } \\
\text { (As_O5) }\end{array}$ & $\begin{array}{l}\text { Arseni- } \\
\text { ous oxid } \\
\left(\mathrm{A} \mathrm{S}_{-} \mathrm{O}_{3}\right)\end{array}$ & $\begin{array}{c}\text { Soluble } \\
\text { arsenious } \\
\text { oxid } \\
\left(\mathrm{A} \leq \mathrm{O}_{3}\right) .\end{array}$ \\
\hline a $2: 1$ & Di-pa:ene ...... & $\begin{array}{r}\text { Ier cent. } \\
\quad 40.40\end{array}$ & $\begin{array}{r}\text { Per cent. } \\
35.50\end{array}$ & $\begin{array}{r}\text { Per cent. } \\
13.2 s\end{array}$ & $\begin{array}{l}\text { Per } c \text { nt. } \\
\text { …..... }\end{array}$ & $\begin{array}{l}\text { Ier cent. } \\
\text {............ }\end{array}$ \\
\hline & & $\begin{array}{l}56.61 \\
29.00\end{array}$ & $\begin{array}{l}39.14 \\
40.60\end{array}$ & $\begin{array}{r}14.83 \\
\cdots .2 .\end{array}$ & ${ }^{\prime}$ i 21.20 & \\
\hline e.293 & .....c. co & $f 35.30$ & 32.31 & ..... & a 30.00 & $\ldots$ \\
\hline e:295 & co & $f 37.40$ & $\begin{array}{l}44.40 \\
44.98\end{array}$ & & $\begin{array}{l}\text { d } 18.00 \\
\text { d } 14.70\end{array}$ & $\therefore$ \\
\hline e 296 & do & $3 \because .2$ & 34.83 & $\because$. & il 30.62 & * \\
\hline $\begin{array}{ll}2 & 28 \\
89\end{array}$ & l'ink Arsenoir ..... & .31 & 49.58 & (.......... & 43.26 & 3.24 \\
\hline 188 & & & 49.09 & & 49.19 & 1.93 \\
\hline
\end{tabular}

$a \mathrm{All}$ the lead oxid calculated to $\mathrm{Pb}_{3}\left(\mathrm{AsO}_{4}\right)_{2}$ leaves an excess of 0.05 per cent arsenic oxid, probably combined as sodium arsenate.

$b$ All the lead oxid calculated to $\mathrm{Pb}_{3}\left(\mathrm{AsO}_{4}\right)_{2}$ leaves an excess of 1.38 per cent arsenic oxid, probably combined as sodium arsenate.

c'This analysis was made in accordance with the Texas law regulating the sale of Paris Grecn and other insecticides and is good only until May 1, 1903. In addition to constituents named, 2.7 per cen organic matter was found.

1 The chemist reported arsenic in the following ways on these 5 samples: (1) White arsenic, (2) total arsenic, (3) white arsenic, (4) white arsenic, (5) arsenious oxid. Thesc terms are usually applied to arsenic when in the "ous" condition and mean so much $\mathrm{As}_{2} \mathrm{O}_{3}$. If these compounds are arsenates, as claimed, the arsenic should be reported as $\mathrm{As}_{2} \mathrm{O}_{5}$. In several of the above analyses, however, if the figures as given were calculated to $\mathrm{As}_{2} \mathrm{O}_{3}$, the sum total of the constituents would be markedly above 100 per cent.

c Analysis made according to Texas law, but good only until May 1, 1902.

$f$ Includes orgunic matter also.

g In addition to constituents named 6.85 per cent of organic matter, lead sulphate, ete., was found

It is at once evident that the variation in the composition of samples of Lead Arsenate is considerable, depending to a large extent on the variation in the moisture content and somewhat on the variation in method of manufacture. These differences in composition should be borne in mind in using such compounds for spraying purposes, since some of them would not have the same insect-killing powers as other's at the same dilution. Pink Arsenoid, although somewhat variable in composition, is much more constant than is Lead Arsenate.

XX, PURILE POISON, ANI) INSECTICIDE.

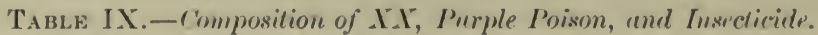

\begin{tabular}{|c|c|c|c|}
\hline Constituents. & $\frac{\mathrm{XX}}{(\mathrm{No} .18 \overline{)})}$ & $\begin{array}{c}\text { Purple } \\
\text { P'oisonl } \\
(\text { No. 304)." }\end{array}$ & $\begin{array}{l}\text { lusect icide } \\
\text { (No. 308).a }\end{array}$ \\
\hline Total arsenious oxid & $\begin{array}{r}\operatorname{Per} c e n t \\
33.71\end{array}$ & $\begin{array}{r}\text { I'er cent. } \\
30.6\end{array}$ & $\begin{array}{r}\text { I'er cent. } \\
8.00\end{array}$ \\
\hline 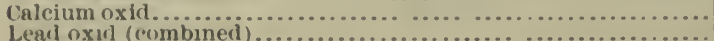 & ........... & 8.5 & \\
\hline 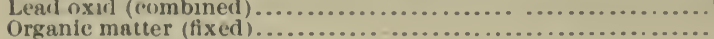 & $\cdots \cdot$ & $\cdots \ldots \ldots \ldots$ & $\begin{array}{l}15.90 \\
66.60\end{array}$ \\
\hline 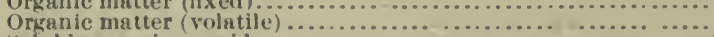 & & .... & $\begin{array}{r}0.60 \\
9.50\end{array}$ \\
\hline soluble arsenious oxid ................ & 32.23 & $\ddot{9} . \overline{5}$ & 8.00 \\
\hline
\end{tabular}

aThe Purple Poison, sample No. 304, also contains coloring matter. The two mulyses, Nus, 304 and 30 s were made in accordance with the Texas law regulating the sale of p'aris (itcen (see page bil) and other insecticides and holds goorl only until .lay 1, 1903. 
None of the three analyses is sufficiently complete to show definitively the chemical composition of the compound exanined, although from the data as given the Purple Poison appears to be at least partially composed of I condon Purple or some closely allied product.

(UIPER C'ARHONATE.

[No. 2s I and W.]

The analysis of this sample in the Bureau of Chemistry showed that it contained 58.24 per cent of total copper oxid. It is basic in chaiacter and of somewhat variable composition, so that the purity can not be calculated from the copper-oxid content. It contains, however, a somewhat smaller anount of copper oxid than other samples examined in this laboratory. The method of analysis used was that described in Bulletin 68 .

FostITE.

Composition of fostite.

[No. 280.]

Per cent.

Loss at dull-red heat.......................... 2.92

Soluble in aqua regia:

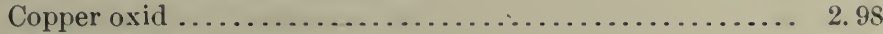

Ferric oxid and alumina........................ 1.36

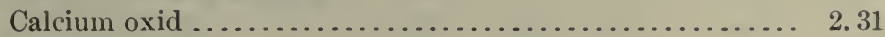

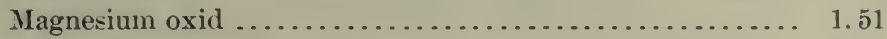

Sulphur trioxid ............................ 3.28

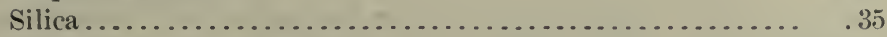

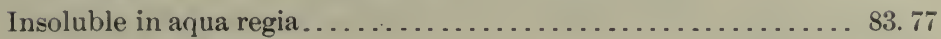

Soluble in hot water.......................... 79

This material is said by the analyst to be composed of copper sulphate and finely powdered soapstone in the ratio of approximately 1:9.

SULPHATINE AND DEATH TO ROSE BLGS.

Table X.-Composition of Sulphatine und Death to Riose Bugs.

\begin{tabular}{|c|c|c|}
\hline Constituents. & $\begin{array}{l}\text { Sulphatine } \\
(\text { (No.120). }\end{array}$ & $\begin{array}{c}\text { Death to } \\
\text { Rose Bugs } \\
\text { (సo.121). }\end{array}$ \\
\hline 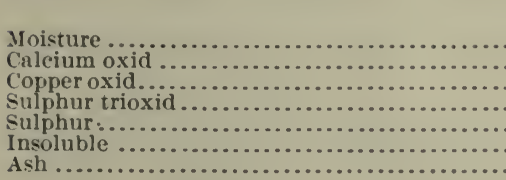 & \begin{tabular}{r|} 
Per cent. \\
1.40 \\
18.60 \\
2.61 \\
4.73 \\
48.28 \\
1.63
\end{tabular} & $\begin{array}{r}\text { Per cerrt. } \\
2.95 \\
17.76 \\
1.05 \\
4.35 \\
34.53 \\
54.14\end{array}$ \\
\hline
\end{tabular}

Neither of the above substances has ever been examined in this laboratory, but from the analyses it would appear that sulphur and copper, probably as copper sulphate, are the active constituents. These are diluted with inert materials, probably to mitigate their action upon the foliage. 
SOAPS.

TABLE XI.-Composition of whale-oil soups.

\begin{tabular}{|c|c|c|c|}
\hline Sample No. & Moisture. & $\begin{array}{l}\text { Potash } \\
\text { lye. }\end{array}$ & Sodulye. \\
\hline $\begin{array}{l}171 \ldots \ldots \ldots \\
172 \ldots \ldots \\
173 \ldots \ldots \\
174 \ldots \ldots\end{array}$ & $\begin{array}{r}\text { Per cent. } \\
27.30 \\
71.58 \\
6.22 \\
6.25\end{array}$ & $\begin{array}{r}\text { Per cent. } \\
10.55 \\
6.86 \\
13.86 \\
10.66\end{array}$ & $\begin{array}{r}\text { Percent. } \\
7.54 \\
4.89 \\
9.90 \\
7.61\end{array}$ \\
\hline
\end{tabular}

The above analyses do not indicate that both soda and potash are present, but show how much of either would be present calculated from the number of cubic centimeters of normal acid necessary to neutralize a known weight of soap.

I.YES.

The compiled analyses of a number of samples of lyes and the results on one sample (No. $24 \mathrm{I} \& \mathrm{~W}$ ) examined in this laboratory are given in Table XII.

\section{TaBle XII.-Composition of lyes.}

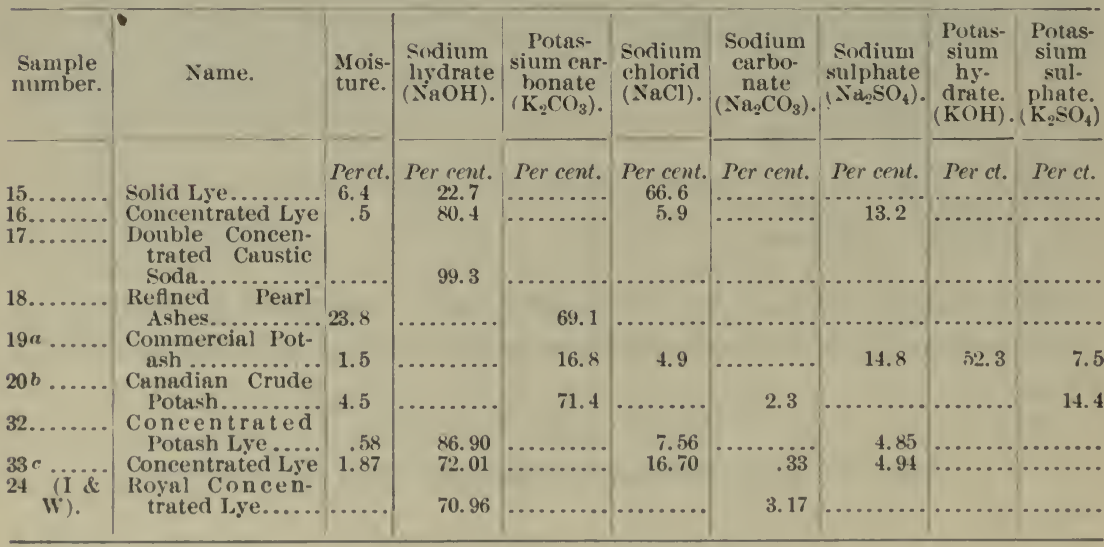

$a$ The following constituents were also determined: 2.1 per cent insoluble, and 0.1 per cent silica.

b The following constituents were also determinerl: 3.6 per cent potassium chlorid, $41,2.7$ per cent insoluble.

$c$ The following eonstituents were also found: 0.06 per cent of alumina und traces of ferric oxid, magnesium oxid, and insoluble.

The method used for the analysis of the Royal Concentrated Lye (No. $2+$ I \& W) is as follows:"

The lye is weighed in a weighing bottle, dissolved to a definite volume in carbondioxid-free water and aliquot portions taken for analysis. Phenolphthalein is adderl to one of these portions and $\mathbf{N} / 3$ potassium acid sulphate is arded at the rate of about a drop per second, with constant stirring until the pink color fades and the solution hecomes colorless. The number of ce of $\mathrm{N} / 3$ acid used, "n" represents the 
sodium hydroxid and one-half the sodium carbonate, since the sodium carbonate is changed to sodium bicarbonate $\left(\mathrm{NaHCO}_{3}\right)$. A drop of methyl orange is arlded and the titration continned until the appearance of a pink color. Let this number of ec be represented by "m." Since this last titration represents the sodium bicarbonate present or one-half the sodium carbonate, " $2 \mathrm{~m}$ " represents all the sodium carbonate, and "n-m" the sodium hydroxid.

The figures in most cases explain themselves, although a few remarlis emphusizing certain points might not be out of place. Sample No. 15 is evidently a very poor example of a soda lye, as two-thirds of it is composed of sodium chlorid. No. 16 is a rery fair sample of caustic soda, while No. 17 is a most excellent sample of the same goods. No. 32 is not a potash lye, as it claims to be, but a soda lye. Nos. 32,33 , and $24 I \& W$ are all fair samples of commercial soda lye.

\section{HELLFYORES.}

TABLE XIII.-Composition of hellebores.

\begin{tabular}{|c|c|c|c|c|c|}
\hline 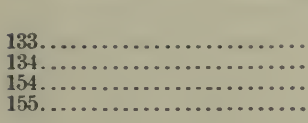 & $\begin{array}{r}\text { Per cent. } \\
2.34 \\
38.12 \\
\ldots \ldots\end{array}$ & $\begin{array}{l}\text { Per cent. } \\
\cdots \\
\cdots \\
33.13 \\
16.00\end{array}$ & 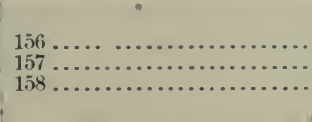 & \begin{tabular}{|c}
\multicolumn{2}{|c}{ Per cent. } \\
$\cdots \cdots$ \\
$\cdots \cdots$ \\
$\cdots \cdots$
\end{tabular} & $\begin{array}{r}\text { Per cent. } \\
12.00 \\
10.60 \\
34.00\end{array}$ \\
\hline
\end{tabular}

Samples Nos. 134,154 , and 158 are evidently badly contaminated with dirt, probably because the roots of the plant were not properly cleaned. Sample No. 155 also appears to have a slightly higher ash content than should be allowed in preparations of this kind.

\section{MIXTURES ('ONTAINING BORAX.}

A single example of this class of compounds, the analysis of which was made in this laboratory, is given below:

HOOKER'S COCKROACH AND WATER BUG EXTERMINATOR.

Composition of Hooker's Cockroach and Water Bug Exterminatoi.

Per cent.

Camphor

$3.5-4.0$

$\operatorname{Borax}\left(\mathrm{Na}_{2} \mathrm{~B}_{4} \mathrm{O}_{7} 10 \mathrm{H}_{2} \mathrm{O}\right)$

92.25

Ammonia $\left(\mathrm{NH}_{3}\right)$

.27

'The remainder is principally organic matter and appears to be tobacco. The ammonia seems to be present as ammonium carbonate.

In making an analysis of this compound the camphor was determined by extracting the powder with ether, allowing it to evaporate at room temperature and weighing at once. While this method leaves 
much to be desired, it at least gives approximate results when a large portion of the material is used. The borax was determined by the same method as given in Bulletin $6 s \mathrm{for}$ similar compounds, except that the ammonia was all driven off from the solution by boiling before the boric acid was determined.

This mixture would very likely be efficacious in driving away cockroaches and water bugs, hut probably it would not kill them.

\section{TOBACCO EXTRACTS.}

1

The analyses of fire samples of tobacco extracts are given in Table XIV. In two of these only the most important constituent, nicotin, was determined, while in one of them the determination of this constituent was not made.

TABLE XIV.-Composition of tobaceo extracts.

\begin{tabular}{|c|c|c|c|c|c|}
\hline Constituents. & $\begin{array}{l}\text { Sample } \\
\text { No.116.a }\end{array}$ & $\begin{array}{l}\text { Sample } \\
\text { No.117.b }\end{array}$ & $\begin{array}{l}\text { Sample } \\
\text { No. } 130 .\end{array}$ & $\begin{array}{l}\text { Sample } \\
\text { So. } 131 .\end{array}$ & $\begin{array}{l}\text { Sample } \\
\text { No. 132. }\end{array}$ \\
\hline Moisture & $\begin{array}{r}\text { Per cent. } \\
37.710\end{array}$ & $\begin{array}{r}\text { Per cent. } \\
40.890\end{array}$ & $\begin{array}{l}\text { Per cent. } \\
\text {-........... }\end{array}$ & $\begin{array}{l}\text { Per cent. } \\
\text {........... }\end{array}$ & $\begin{array}{l}\text { Pèr cent. } \\
10.00\end{array}$ \\
\hline sh. & 19.420 & 27.770 & & & ........... \\
\hline Tot & 2.010 & 1.730 & & & \\
\hline as nitrate & $\therefore 1$ & 530 & & & \\
\hline xid and alumin & $\begin{array}{r}2.115 \\
.229\end{array}$ & .530 & 4.55 & 4.82 & \\
\hline Calc & 3.069 & 1.466 & & & 4. 45 \\
\hline 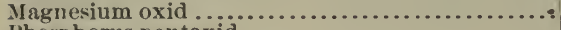 & 2.303 & 1.121 & & & \\
\hline 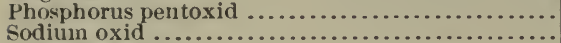 & $\begin{array}{l}.404 \\
.207\end{array}$ & .057 & & & \\
\hline 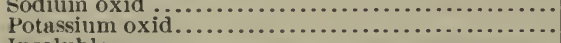 & 6.550 & 16.340 & & & 9.1 \\
\hline Insoluble. & Trace. & & & & 2.1 \\
\hline
\end{tabular}

a Specific gravity, 1.3858 .

b Specific gravity, 1.377 .

In the first four of these samples the nicotin figure is much too low for a good tobacco extract; especially is this true of the first two.

\section{FORMALINS.}

The analysis of three samples of formalin, and the arerage of the results obtained on fire samples, together with one analy made in this laboratory, are given in the following table:

TABLE: XV.-Composition of formalins.

Sample No.

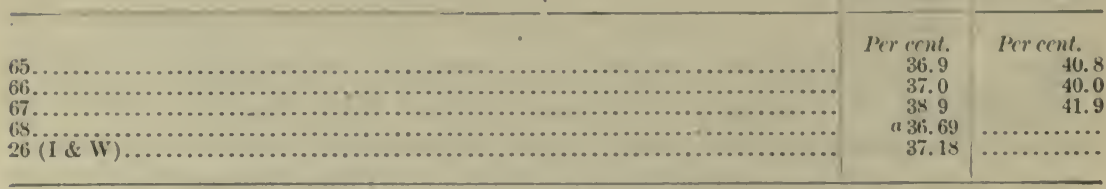

a Average of 5 samples.
Formaldelyde.

By weight. By rolume.

\begin{tabular}{|c|c|}
\hline $\begin{array}{r}\text { Per cent. } \\
36.9 \\
37.0 \\
3 \times 9\end{array}$ & $\begin{array}{r}\text { Iercent. } \\
40.8 \\
40.0 \\
41.9\end{array}$ \\
\hline $\begin{array}{r}36.69 \\
37.18\end{array}$ & . \\
\hline
\end{tabular}

(n) 
The method used for determining formaldehyde in samples 6.5 to 68 , inclusive, is as follows: "

Fifteen culic centimeters of $\mathrm{N} / 10 \mathrm{AgNO}$ are treated with 5 drops of 50 per cent nitric acid in a 50 ce flask. Ten ee of a solution of potassium cyanid (containing 3.1 grams of 96 per cent potassium cyanid in $500 \mathrm{cc}$ of water) are then added, the flask filled to the mark with distilled water, well shaken, and an aliquot portion of the filtrate, say 25 ce, titrated according to the method of Volhart with a $\mathrm{N} / 10$ solution of ammonium sulphocyanate for the excess of silver.

Another 15 ce portion of $\mathrm{N} / 10 \mathrm{AgNO}$ is treated with 5 drops of 50 pere cent nitric acid and $10 \mathrm{cc}$ of the potassium cyanid solution, to which has been adderl a known amount of the formalin solution. The whole is made up to $50 \mathrm{cc}$, and a 25 cre filtrate from it titrated with N/10 ammonium sulphoryanate, the same as before for the excess of silver. The difference between these two results gives the amount of potassium cyanid that has been used by the formaldehyde in terms of $\mathrm{N} / 10$ ammonium sulphocyanate, and since each cubic centimeter of this is equal to 3 milligrams of formalikhyde, we can obtain the amount of formaldehyde that has been acted upon by the potassium cyanid.

The method used in the analysis of sample No. 26. examined in this laboratory, is as follows:

About 3 grams of the solution is weighed into a tall Firlenmeyer flask containing 25 to $30 \mathrm{cc}$ of double normal sodium hydroxid. Fifty ('c of pure 2.5 to 3 per cent fresh hydrogen peroxid is then gradually added, during a space of three minutes, through a funnel placed in the neck of the flask to prevent spurting. After standing ten minutes the funnel is washed with water and the unused sodium hydroxid titrated with double normal sulphuric acid, using litmus as indicator. By this method the formaldehyde is oxydized to formic acid, which is neutralized hy the sodium hydroxid present.

While samples Nos. 65, 66, 67, and 26 I \& $\mathrm{W}$ all contain less than 40 per cent formaldehyde by weight they contain 40 per cent or over by volume, so that the manufacturers are perfectly correct in claiming that their goods contain as much as 40 per cent of formaldehyde.

I'ETROLEUMS.

The results obtained by fractionally distilling four samples of crude petroleum are given in the following table:

TABLE XVI.-Composition of erude petroleum.

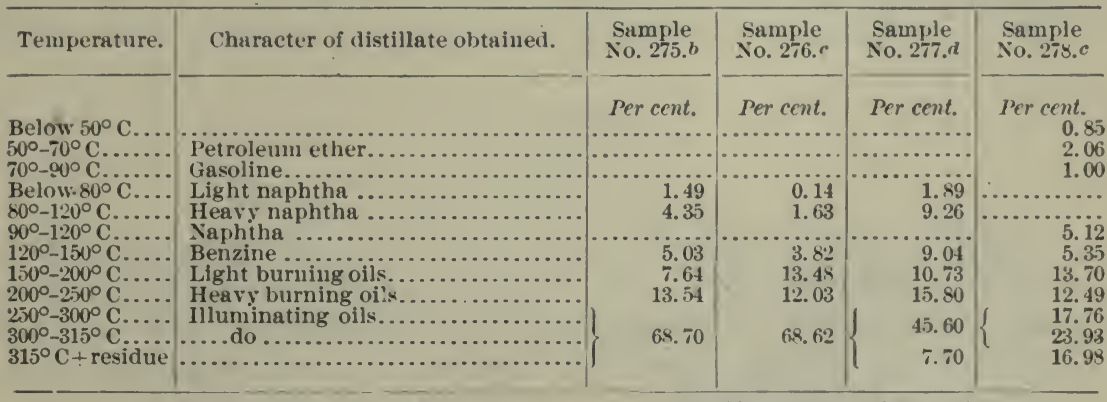

a Zeit fur anal. Chemie, $189 \%$, p. 19. b Specific gravitỹ, $35^{\circ}$ Baumé. c Specific gravity, $34^{\circ}$ Baumé d specific gravity, $45^{\circ}$ Baumé. 
MISCELLANEOUS SOLII) IXSECTICIDES ANI) FLNGICIDES.

The analyses of a number of solid insecticides and fungicides that do not come under any of the previous headings are given in the following tables:

SLTLPHCKS.

TABLE XVII.-Compositiou of sulphur.

\begin{tabular}{|c|c|c|}
\hline Constituents. & $\begin{array}{l}\text { Sample } \\
\text { No. } 35 \text {. }\end{array}$ & $\begin{array}{l}\text { Sample } \\
\text { No. } 36 .\end{array}$ \\
\hline 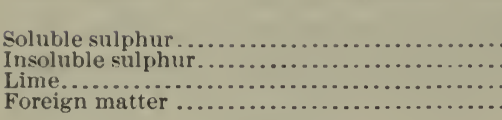 & $\begin{array}{r}\text { Per cent. } \\
99.960 \\
.144 \\
.000 \\
.196\end{array}$ & $\begin{array}{r}\text { Per cent. } \\
98.660 \\
.576 \\
\text { Trace. } \\
.764\end{array}$ \\
\hline Total.. & 100.300 & 100.000 \\
\hline
\end{tabular}

The total for sample No. 35 is given by the chemist who made the analy sis as 100 per cent, but all the constituents added together amount to 100.3 per cent, as above.

PINE TAR INSECTICIDES.

[No. 73.]

This is an insecticide obtained from the destructive distillation of pine knots. It readily mixes with water and is slightly sticky and greasy.

BCG DEATHS.

Table XVIII.-Composition of lug deathe.

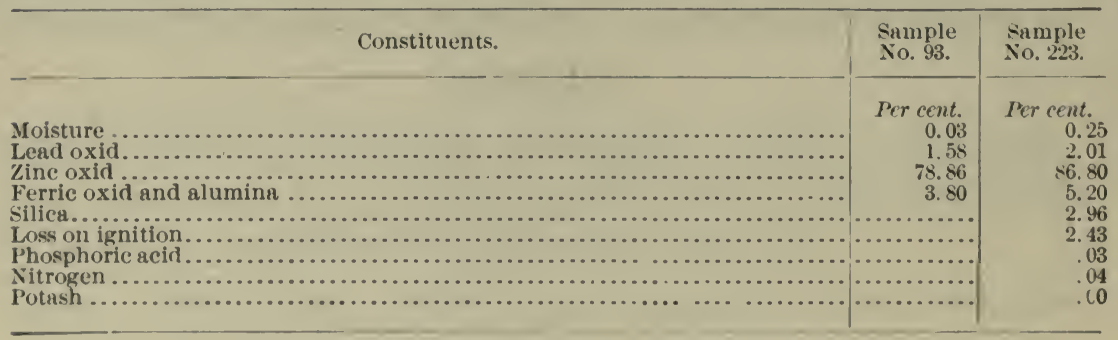

POTASIUN CYAXID.

[Nos. 23 and 1170 I \& W.]

Sample No. 23 contained 53.12 per cent of potassium cyanid calculated from the cyanogen. The remainder of the sample appeared to consist principally of moisture and some potassium carbonate and chlorid. The method of analysis used was that described in Bulletin 68 , Bureau of Chemistry. 
Compoxition of potassium ryanid.

[No. 1170, I \& W.]

I'er cent.

Cyanogen

40. 49

Potassium

21.48

Sodium

23. 74

Chlorin

8.98

Carbonic acid radical

Moisture

Undeterminerl

100.00

The above analyses show that both samples of potassium cyanid are very impure, although the second sample contains just about the amount of eyanogen demanded by theory.

NONPOINONOUS POTATO-BLG IOETROYER.

Composition of nompoisonous potato-lug destroyer.

[No. 137.]

Moisture

Per cent.

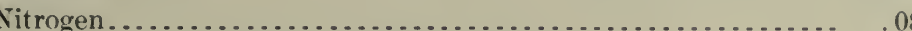

Ash ................................................. 79. 85

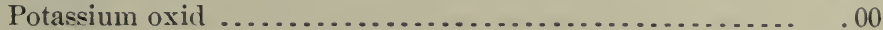

Calcium oxid .................................. 68.20

Magnesıum oxid ................................ 7.29

Ferric oxid and alumina . . . . . . . . . . . . . . . . . . 38

Phosphorus pentoxid ............................. Trace.

Insoluble before calcination .......................... 7.29

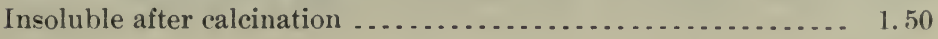

As this analysis is not complete, no opinion as to the substances of which the mixture is composed can be expressed.

NONPOISONOYS INSECT EXTERMINATOR.

[No. 151.]

This sample contained 78.12 per cent of lime and 3.61 per cent crude earbolic acid, determined as ether extract. It had an odor of carbolic acid and appeared to be partly composed of carbolate of lime.

x. o. DUST.

[No. 176.]

Composition of $\boldsymbol{X}$. O. Dust.

Per cent.

Moisture

6.98

Organic and volatile matter

53.69

Carbon dioxid

3. 40

Carbolic acid

Trace. 


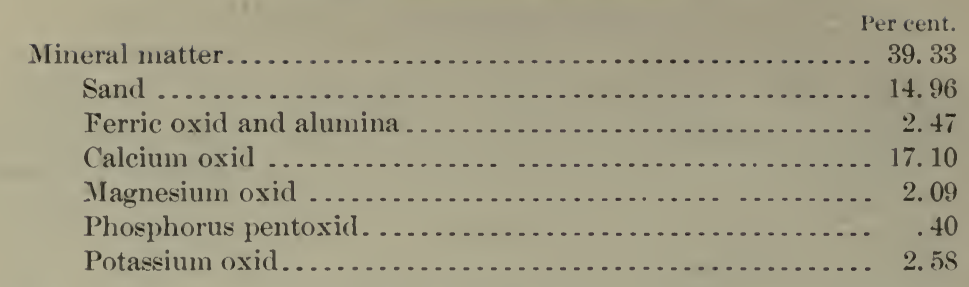

This mixture appears to be partly composed of carbonate of calcium with an excess of lime. No opinion as to the character of the organic and volatile matter can be based upon the data given, exclusive of the carbolic acid already mentioned.

ELECTRIC VERMIN EXTERMINATOR.

[No. 197.]

This insecticide is chiefly a mixture of calcium carbonate and calcium hydroxid with a very small amount of organic matter. Upon examination in this laboratory the organic matter present was found to consist of carbolic acid.

P'AR' (HI)IUY.

[No. 281.]

From the analyst's report this product would appear to consist of silicate of iron mixed with calcium sulphate. The analysis does not show the presence of sulphur and tobacco, both of which were found on examining a sample of the product in this laboratory.

\section{ANTINONNIN.}

[No. 2*2.]

A qualitative test of this substance showed that it contains dinitrocresols, together with soap and glycerin.

\section{MISCELLANEOUS LIQUID INSECTIUIDES AND FUNGICIDES.}

BOLLENE INSECTICIDE.

Composition of somples Nos. 305, 644, 645.

[No. 303.]

Per cent.

Carbon bisulphid............................... 47.8

Mineral and essential oils.......................... 12.2

Water and residue ................................ 40

This analysis was made in accordance with the Texas law (see p. 61) regulating the sale of Paris Green and other insecticides and is good only until May 1, 1903. 
[Nos. (it4 and 6ids (I \& W).]

Of the two samples of this product received at the Bureau of Chemistry one consisted of a black oil (6t4), while the other (645) separated into two layers, one a black oil and the other a white milky emulsion. The first sample was fractionally distilled as it stood, and the second sample was separated into its two parts and each part subjected to fractional distillation.

\section{No. 6.4 (I (C. II) , results of distillation test.}

P'er cent.

Below $95^{\circ} \mathrm{C}$ 151.07

$95^{\circ}-108^{\circ} \mathrm{C}$ b. 41

$108^{\circ}-130^{\circ} \mathrm{C}$

$130^{\circ}-160^{\circ} \mathrm{C}$

$160^{\circ}-190^{\circ} \mathrm{C}$

$300^{\circ}-350^{\circ} \mathrm{C}$

ค 6.16

3วั0 $0^{\circ} \mathrm{C}$. +

c. 1.02

Loss and residue.

a Practically all carbon bisulphid.

$b$ Penetrating odor of some essential oil.

$c$ Odor of petroleum products with paraffin which erystallizes out in the higher fructions.

\section{No. 645 ( $I$ \& $\left.\mathrm{WW}^{\prime}\right)$, results of distillation test.}

WHITE EMULSION, 81.28 I'ER CENT.

Below $95^{\circ} \mathrm{C}$

Per cent.

$95^{\circ}-108^{\circ} \mathrm{C}$.

a 1.24

$108^{\circ}-130^{\circ} \mathrm{C}$

b 76.10

Loss and residue.

c 13.47

9. 19

BLACK OIL, 18.72 PER ('ENT.

Below $40^{\circ} \mathrm{C}$

$95^{\circ}-108^{\circ} \mathrm{C}$

$108^{\circ}-130^{\circ} \mathrm{C}$

$130^{\circ}-160^{\circ} \mathrm{C}$

Residue and loss 
It is evident from the analyses of the two samples of bollene insecticide made in the laboratory that the first one $\left(6+4 \mathrm{I} \& \mathrm{~W}^{\prime}\right)$ consists of abont 50 per cent carbon bisulphid and 50 per cent erude petroleum with a rery small quantity of some essential oil having a strong odor, while the second ( $6+5 \check{I} I \& \mathrm{~W}^{*}$ ) consists of about 62 per cent water, 14 per cent carbon bisulphid, and 23 per cent petroleum, with a little essential oil and a small quantity of soap. Whether or not a compound of this composition, which is evidently very variable, would kill the bollworm is a matter for experimentation.

The results of the analyses of these two samples were forwarded to the manufacturer, who in reply said: "This analysis is not at all correct, and since the analysis was made I have perfected my preparation." Another letter was then sent, asking in what particular the analysis was unsatisfactory, but to this no reply was received. The analyses of these samples was repeated, but the same results were obtained. Besides this it is found that the analyses made in this laboratory gave very much the same results as those made by the Texas authorities from a qualitative standpoint. Unless the results obtained by the Texas authorities and by this laboratory are approximately correct the manufacturer is selling all of his goods under a false label, since the Texas law requires that all insecticides sold in the State shall comply with the official analysis on every package.

EXCEISIOR INSECTI(IDE ANI) WOOD PRESERVER, RED ('EDAR BRAND.

[No. 63, I \& W.]

Results of distillation test.

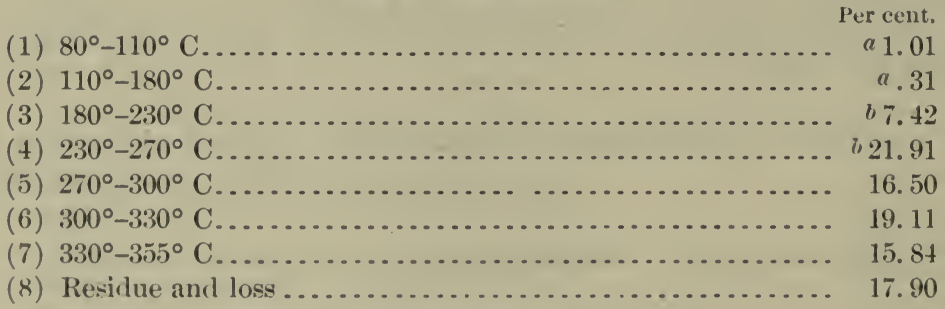

" Light oils with odor of benzene, toluene, etc.

$b$ Give tests for phenol and cresols.

Fractions $4,5,6$, and 7 are heavier than water. At about $340^{\circ} \mathrm{C}$. the distillate begins to solidify in the condenser, and at $355^{\circ} \mathrm{C}$. the condenser is so stopped up with naphthalene that it is necessary to cease distilling. 'This appears to be a sample of coal-tar creosote, and when properly used is of value both as an insecticide and a wood preserver. 
FI,Y I'REV FATATIVE.

[No. 20:2, 1 \& W.]

Resulls of distillation test.

Per cent.

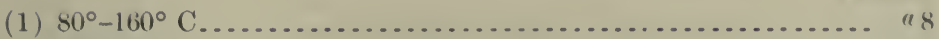

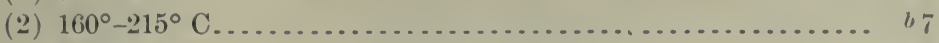

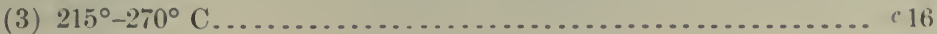

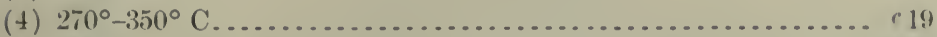

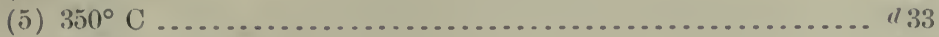

(6) Residue and loss ............................ 17

" Light oil giving test for phenol and cresols.

b) Heavier oil giving test for phenol und eresols.

e Thick oils.

"Thick oil with solid particles.

e Solid when cooling.

Fractions $1,2,3,4$, and 5 are all lighter than water. From the above analysis this sample appears to be a mixture of coal-tar creosote and petroleum. These substances are often used as fly preventatives.

KARBO KRESOLATE.

[No. 916, I \& W.]

Results of distillation test.

Per cent.

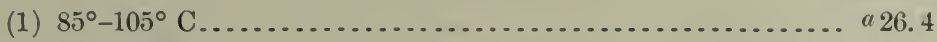

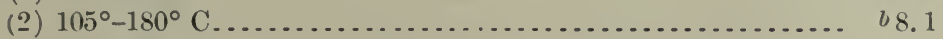

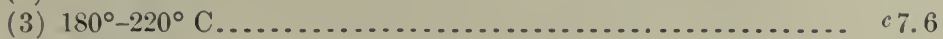

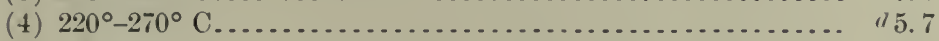

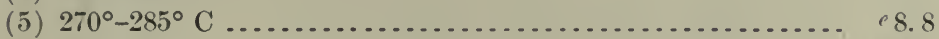

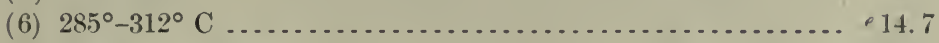

(7) Residue and loss.............................. 28. 7

a Light oil and water mixed; smell of carbon bisulphid and benzine.

$b$ Light oil, test for phenol and cresols.

$c$ Oil, heavier than water, test for phenol and cresols.

$d$ Oil heavier than water.

e Thick oil; pungent odor.

Fractions 3 and 4 contain solid naphthalene. A small amount of alkali is also present. From the distillation test it would appear that this sample consists of .coal-tar creosote which has been boiled with resin and an alkali, or with resin, fatty matter, and alkali, to cause it to form an emulsion with water. From the size, appearance, and smell of the first fraction it also appears that some carbon bisulphid has been added. It is well known that creosote emulsions have given good results both as disinfectants and sheep dips. This preparation, therefore, would rery likely be of value for the purposes intended. 
PROFESSOR DE GRAFF'S CARPET BUG DESTROYER.

Composition of Professor Ite Ciraff's C'arpet Bug Destroyer.

\begin{tabular}{|c|c|c|}
\hline ('onstituents. & $\begin{array}{l}\text { Sample } \\
\text { No. } 122 .\end{array}$ & $\begin{array}{l}\text { Sample } \\
\text { No. } 129 .\end{array}$ \\
\hline $\begin{array}{l}\text { Moisture ................... } \\
\text { Residue from evaporation.. }\end{array}$ & $\begin{array}{r}\text { Per cent. } \\
95.811 \\
4.189 \\
\end{array}$ & 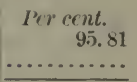 \\
\hline 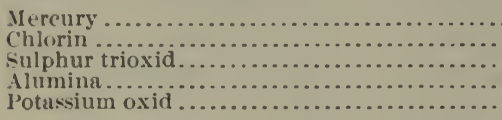 & $\begin{array}{l}.782 \\
.265 \\
.484 \\
.904 \\
.267\end{array}$ & $\begin{array}{l}.78 \\
.27 \\
.48 \\
.90 \\
.26\end{array}$ \\
\hline
\end{tabular}

These two analyses are given in two different reports of the Massachusetts State Experiment Station, but were very likely made upon the same samples, since they are identical.

The active poisonous principle of this solution is evidently mercuric chlorid, which is often used for the destruction of various insects which infest houses. 


\section{STATE LAWS GOVERNING THE CONPOSITION AND SALE OF' INSECTICIDES.}

A circular letter was sent to the various experiment stations asking that they forward copies of the laws in their respective States relative to the composition and sale of Paris Green and other insecticides. In eases where the experiment stations could not furnish the information a similar request was made of the secretary of state. It is believed that the following compilation of State laws is a complete résumé of all such laws passed in the United States.

\section{CALIFORNIA.}

AN ACT to prevent frand in the sale of Paris Green used as an insecticide.

The people of the State of California, represented in senute and assembly, do enuct as follous: It shall be the duty of each and every manufacturer of Paris Gireen (commer(ial aceto-arsenite of copper) to be used as an insecticide within this State, and of every dealer in original packages of said Paris Green manufactured outside of this State, before the said Paris (ireen is offered or exposed for sale, or sold within this State as an insecticide, to submit to the director of the California experiment station, at Berkeley, samples of said Paris Green, and a written or printed statement setting forth: First, the brand of said Paris Green to be sold, the number of pounds contained in each package in which it is put on the market for sale, the name or names of the manufacturers and the place of inanufacturing the same; second, the statement shall set forth the amount of combined arsenic which the said Paris Green contains, and the statement so furnished shall be considered as constituting a guarantee to the purchaser that every package of such Paris Green contains not less than the amount of combined arsenic set forth in the statement.

SEc. 2. Every purchaser of said Paris Green in original packages which is manufactured outside of this State, who intends to sell or expose the same for sale, and every manufacturer of said Paris Green within this State, shall, after filing the statement above provided for with the director of the California agricultural station, at Berkeley, receive from the said director a certificate stating that he has complied with the foregoing statements, which certificate shall be furnished without charge therefor. Said certificate when furnished shall authorize the party when receiving the same to deal in this State in the said Paris Green. Any person who fails to comply with the terms of section 1 of this act shall not be entitled to such certificate and shall not be entitled to deal in said Paris Green within this State. Nothing in this section shall be construed as applying to retail dealers selling sair Paris Green which has already been labeled and guaranteed.

SEc. 3. Paris Green, when sold, offered, or exposed for sale as an insecticide in this State shall contain at least 50 per centum of arsenious oxide and shall not contain more than 4 per centum of the same in the uncombined state.

SEC. 4. The director of the California State agricultural station, at Berkeley, shall examine or cause to be examined different brands of Paris (ireen sold, offered, or exposed for sale within this State, and cause samples of the same to be analyzerl, and 
shall report results of analysis forth with to the secretary of the State board of horticulture and to the party or parties submitting such samples, and such report shall be final as regards the quality.

SEC. 5. Any person or persons, firm, association, company, or corporation violating any of the provisions of this act, and any person who shall sell any package of Paris Green, or any part thereof, which has not been labeled as herein provided, shall be guilty of a misdemeanor, and shall be fined not less than $\$ 50$ nor more than $\$ 200$, together with cost of the suit, in an action causerl to be brought by the State board of horticulture, through its secretary, in the name of the people of the State of California.

SEc. 6. The attorney-general of the State of California is charged with the prosecution of all such suits.

SEC. 7. This act will take effect immediately.-Became a lun by constitutiomal limitution Felmary 28, 1901.

\section{LOUISIANA.}

Act No. 131 of the general assembly of the State of Louisiana.

Be it enacted by the general assembly of the Stute of Louisiana, That the bureau of agriculture shall be charged with the duties of regulating the sale and purity of Paris Green as an insecticide in this State.

SEc. 2. That it shall be the duty of any manufacturer or dealer in original packages of Paris Green before the same is offered for sale in this State, to submit to the commissioner of agriculture a written or printed statement setting forth: First. The brand of Paris Green to be sold, the number of pounds contained in each package in which it is to be put upon the market for sale, and the name or names of the manufacturers and the place of manufacture. Second. The statement setting forth the amount of arsenic which they are willing to guarantee the said Paris Green to contain, and the statement so furnished shall be considered as constituting a guarantee to the purchaser that every package of said Paris Green contained not less than the amount of arsenic set forth in the statement.

SEc. 3. That every purchaser proposing to deal in Paris Green shall, after filing the statement above provided for with the commissioner of agriculture, receive from the said commissioner of agriculture a certificate stating that he has complied with the foregoing section, which certificate shall be furnished by the commissioner without any charge therefor; that the said certificate when furnished shall authorize the party receiving the same to deal in this State in Paris Green; that no person who has failed to file the statement aforesaid and to receive the certificate of authority aforesaid shall be authorized to deal in this State in Paris Green, and any person so dealing in this State without having filed the aforesaid statement and received the certificate aforesaid shall be liable for each violation to a fine not excerding $\$ 250$, which fine shall be recoverable before any court of competent jurisdiction at the suit of the commissioner of agriculture or of any citizen, and shall be disposed of as hereinafter provided; provided, further, that nothing in this section shall be construed as preventing the sale by retail dealers throughout the State of Paris Green which has already been guaranteed and labeled as provided for in this act.

SEc. 4. That it shall be the duty of the board of agriculture, or its commissioner, at the opening of each scason, to issue and distribute circulars setting forth the brands of Paris Green, their percentages of arsenic as claimed ly the dealers, and to more particularly describe them they shall be separated into two classes, viz: First, those brands containing 50 per cent or more of arsenic shath he classed as "strictly pure," and, second, all falling below this percentage shall be classed as "impure."

SEC. 5. That it shall be the duty of the commissioner of agriculture to cause to be prepared labels of suitable naterial, fitted to be attached to packages of Paris Green and to have printed thereon "guaranteed," with a blank space into which there may 
be stamper by the commissioner of agriculture the words "strictly pure," or "impure," as the guarantee may require; also the year or season in which it is to be used and a facsinile of the signature of said commissioner. The said labels shall be furnished by the said commissioner, to any dealer in P'aris Green who shall lave complied with the foregoing provisions of this act, upon the payment by said clealer to said commissioner of fifty cents for a sufticient number to label one hundred pounds of Paris Green.

SEC. 6. That it shall be the duty of every person, before offering for sale any Paris Green as an insecticide in this state, to attach or cause to be attached to each package one of the labels hereinhefore described, designating the quantity of Paris (ireen in the package to which it is attached. Any person who shall sell any packages of Paris Green, or any part thereof, which has not been labeled as herein provided for shall he guilty of a nisdemeanor, and on conviction thereof shall be fined in the sum of one hundred dollars for each omission, which penalty may be sued for either by the Commissioner of Agriculture or any person for the uses hereinafter declared. Any person who shall counterfeit or use a counterfeit label prescribed by this act, or who sliall use them a second time, shall be guilty of a misdemeanor, and on conviction thereof shall be fined in a sum not exceeding two hundred and fifty dollars, one-half of which shall be paid to the informer, which may be doubled or trebled at each second or third conviction, and so on progressively for subsequent convictions.

SEC. 7. That it shall be the duty of every person who sells a package of Paris (ireen, upon the request of the purchaser, to draw from the same and in the presence of the purchaser or his agent a fair or correct sample and to have the same securely enclosed and sealed and sent to the Commissioner of Agriculture for analysis by the official chemist of the State, and if upon analysis the said Paris (ireen shall be found below the guarantee given to the Commissioner of Agriculture and printed on the package, then the said seller shall be liable to the said purchaser for all damage accruing from said difference, recoverable in any court of competent jurisdiction in the State.

SEC. 8. That the copy of the official chemist's analysis of any Paris Green certified to by him shall be admissible as eviclence in any court of the State on trial of any issue involving the merits of said Paris Green.

SEc. 9. That the Bureau of Agriculture shall adopt needful rules and regulations providing for the collecting of money arising from the sale of labels, or for any fines imposed under this act, and shall deposit the same with the Treasurer of the State.

\section{NEW YORK.}

AN ACT to amend the agricultural law, to prevent fraud in the sale of Paris Green.

The P'eople of the State of New York, represented in Senate and Assembly, do enact as follous: Chapter three hundred and thirty-eight of the laws of eighteen hundred and ninety-three entit!ed " $\mathrm{An}$ act in relation to agriculture, constituting articles one, two, three, four, and five, of chapter thirty-three of the general laws," is hereby amended by adding a new article to be known as article eight and to read as follows:

SEC. 110. Sinte manufacturer and the dealer in original packages to file certificate with commissioner of agriculture. After the passage of this act it shall be the duty of each and every manufacturer of Paris green within this state, and of every dealer in original packages of Paris green manufactured outside of this state, before the said Paris green is offered or exposed for sale or sold within this state, to submit to the commissioner of agriculture a written or printed statement setting forth, first, the brands of Paris green to be sold, the number of pounds contained in each package in which it is put upon the market for sale, the name or names of the manufacturers and the place of manufacturing the same; second, the statement shall set forth the amount of arsenic which the said Paris green contains, and the statement so furnished 
shall be considered as constituting a guarantee to the purchaser that every package of such Paris green contains not less than the amount of arsenic set forth in the statement.

SEC. 111. Certificate to be given by the commissioner of agriculture to state mamfacturer and dealer in original packages. Every purchaser of Paris green in original packages, which is manufactured outside of this state, who intends to sell or expose the same for sale, and every manufacturer of Paris green within this State, shall, after filing the statement above provided for with the commissioner of agriculture, receive from the said commissioner of agriculture a certificate stating that he has complied with the foregoing statement, which certificate shall be furnished without any charge therefor; said certificate when furnished shall authorize the party receiving the same to deal in this state in Paris green. Any person who fails to file the statement aforesaid shall not be entitled to such certificate and shall not be entitled to deal in Paris green within this State; nothing in this section shall be construed as applying to retail dealers.

SEc. 112. Composition of Puris green or analogous products. Paris green or any product analogous to it, when sold, offered or exposed for sale, as such, in this state, shall contain at least fifty per centum of arsenions oxille. (See Imendment.)

SEC. 113. Paris green to be analyzed at experiment station. The director of the New York State agricultural experiment station, at Geneva, shall, under the direction of the commissioner of agriculture, examine, or cause to be examined, the lifferent brands of Paris green sold, offered, or exposed for sale within the State, and cause samples of the same to be analyzed, and shall report the result of the analysis forthwith to the commissioner of agriculture.

Sec. 114. Penalty for violations. Any person or persons, firm, association, company, or corporation violating any of the provisions of this act shall be guilty of a misclemeanor, and shall be fined not less than fifty dollars nor more than two hundred dollars; and in addition thereto shall forfeit and pay unto the people of the state of New York the sum of one hundred dollars, together with the costs of the suit in an action caused to be brought by the commissioner of agriculture in the name of the people of the state of New York, as provided by section eight of the agricultural law.

2. This act shall take effect immediately. Became "law March 23, 1898, lny the approval of the Governor. (Laws of New York, ch. 118.)

\section{AMENDMENT TO PARIS-GREEN LAW.}

In accordance with the suggestion made by the New York State Experiment Station in 1900 , that portion of the Paris Green law which related to the definition of Paris Green was changed. The essential portion of the amended law embodying this change is as follows:

SEC. 112. Composition of Puris green or unulogous products. l'aris green, or any product analogous to it, when sold, offered, or exposed for sale as such in this state, shall comply with the following requirements:

First. It shall contain arsenic in combination with (opper, equivalent to not less than fifty per centum arsenious oxirle.

Second. It shall not contain arsenic: in water-soluble forms exuivalent to more than three and one-half per centum of arsenious wxide. 


\section{OREGON.}

Only those sections of the act named below which deal directly with the subject of insecticides are given.

AN AC'T to protect the fruit und hop industry of oragon.

SE: 3. It shall be unlawful for any person, firm or corporation doing lusiness in the State of Oregon to sell paris green, arsenic, london purple, sulphur or any tpray material or compound for spraying purposes, in quantities exceeding one pound, without providing with each package sold a certificate duly signed by the seller thereof guaranteeing the quality and per cent of purity of said materials.

SEC. 4. Any person, firm or corporation selling any of the above materials which do not conform with the certificate furnished therewith shall be deemed guilty of a misdemeanor, and upon convirtion thereof shall be sulject to a fine of not less than twenty-five (\$25) dollars nor more than one humlred (\$100) dollars.

SEC. 8 . It shall be the duty of the Commissioner of the State Board of Horticulture of the district in which a violation of this act occurs to present the evidence of the case to the district attorney, whose duty it shall be to prosecute any person guilty of a violation of this act, which prosecution may be brought in any of the justice courts of this state.

Skc. 9. Inasmuch as the horticultural interests of the state clemand immediate attention, this act shall be in full force and effect from and after its approval by the Governor. Approved by the Governor, February 1\%, 1899.

\section{TEXAS.}

AN ACT for the better protection of the farmer in the purchase of commereial fertilizers and commercial poisons used for destroying bollworms and other pests.

Be it enacted by the Legislature of the State of Texas: Before any commercial fertilizer or commercial poison, or any chemical or mixture used as a commercial fertilizer or commercial poison, such as London purple, arsenic, Paris green, or any poison used for the purpose of destroying the boll worm or other pests, is sold or offered for sale in this State, the manufacturer, agent, importer or party who sells or offers it for sale within this State shall deposit with the professor of chemistry of the Agricultural and Mechanical College a sealed tin can, bottle or jar containing not less than one pound of the fertilizer or commercial poison offered for sale; with an afficlavit that it is a fair sample taken from several barrels, boxes, sacks, or from quantities in larger bulk, of the article thus to be sold or offered for sale; provided the unmixed substances, cotton seed meal, land plaster, salt, ashes, lime, green sand marl, uncrushed bones and animal excrements shall be exempt from the operation of the law.

SEc. 2. The manufacturer, importer, vender or agent of any commercial fertilizer or commercial poison, as referred to in Section 1 of this chapter, shall pay anuually to the treasurer of the Agricultural and Mechanical College an analysis fee of fifteen dollars for each and every fertilizer or commercial poison sold, exposed or offered for sale within this State. Such payment shall be made at the time the sample of fertilizer or commercial poison is submitted to the professor of chemistry for analysis.

SEc. 3. After the analysis fee has been paid, as provided for in Section 2 of this chapter, it shall be the duty of the professor of chemistry of the Agricultural and Mechanical College to analyze or to have analyzed under his direction, any sample of a commercial fertilizer or commercial poison, in accordance with the requirements of the foregoing sections of the law. The professor of chemistry shall print the 
result of such analysis in the form of a label, which shall set forth the name of the manufacturer, the brand of snch fertilizer or commercial poison, and the essential ingredients contained in such fertilizer or commercial poison, viz:

1. Available nitrogen and its equivalent in ammonia.

2. Soluble phosphoric acid; total available phosphoric acid.

3. Reverted phosphoric acirl.

4. Total phosphoric acid.

5. Potash soluble in water.

This, however, shall not preclude the professor of chemistry from setting forth any other ingredient which the fertilizer may contain. And he shall place upon each label the money value of such fertilizer or commercial poison, computed from its composition as he may letermine. He shall furnish such labels in quantities of 500 or multiple thereof at a cost of one dollar per hundred; the money to be paid directly to the treasurer of the Agricultural and Mechanical College.

SEc. 4. Every box, barrel, keg, or other package or quantity of commercial fertilizer or commercial poison (within the limitations of Section 1 of this law), in any shape or form, sold or offered for sale in this State, shall have attached to it in a conspicuous place the label as provided for in Section 3 of this law, with the signature of the professor of chemistry attached.

SEC. 5. The professor of chemistry, or any duly authorized agent of his, is hereby authorized to select from any package of commercial fertilizer or commercial poison sold, or exposed for sale in this State, a quantity not to exceed two pounds, for a sample to be used for the purpose of an official analysis and for comparison with the sample furnished by the manufacturer, agent, or vendor, for official analysis.

SEC. 6. Any manufacturer, agent, or vendor of any commercial fertilizer or commercial poison who shall offer or expose for sale any such fertilizer or commercial poison without having previously complied with the provisions of this chapter shall be fined not less than fifty and not more than five hundred dollars for each violation or evasion of this law.

SEC. 7. Any agriculturist or farmer, a purchaser of any commercial fertilizer or commercial poison in this State, may take a sample of the same under rules and regulations to be prescribed by the professor of chemistry of the Agricultural and Mechanical College and forward the same to him for analysis, which analysis shall be made free of charge.

SEC. 8. The revenues accuing from analysis iees and sale of labels, as provided for in this chapter, shall be expended by the board of directors of the $A$ gricultural and Mechanical College for the maintenance of the chemical department and for such other purposes as they may determine.

SEC. 9. A copy of the official analysis of any fertilizer or comnercial poison, or chemical certified to by the professor of chemistry, shall be admissible as evidence in any court of this State on the trial of any issue involving the merits of said fertilizer or commercial poison.

SEc. 10. Whereas the fact that there is no law authorizing the analysis of commercial fertilizers and commercial poisons, or the testing of arlulterated poisons when used for the purpose of destroying the boll worm and other pests, and the better protection of the farmer, creates an emergency, and an imperative public necessity that the constitutional rule requiring bills to be read on three several days be suspended and that this act take effect and be in force from and after its passage, and gaid rule is so suspended and it is so enacted. Pussed by the Twenty-sixth Legisluture of Texus, 1899. 


\section{WASHINGTON.}

AN ACT to provide ngainst the adulteration of Paris Grecen and other "omponds used for spraying trees and plants.

Be it enacted lyy the Iregislature of the stute of Washington, That it shall hereafter be unlawful for any person, firm, or corporation doing business in the State of Washington to sell or offer for sale alulterated or low grade Paris green, arsenic, London purple, sulphur, or any spray material or compound for spraying purposes.

SEC. 2. For the purposes of this act Paris green shall contain not less than fifty per cent of arsenic trioxide in combination, and not more than four per cent of watersoluble arsenic trioxide, and commercial arsenic shall contain not less than ninetysix $(96)$ per cent of arsenic trioxide.

SEc. 3. Any person, firm, or corporation violating any of the provisions of this act shall be rleemed guilty of a mistemeanor, and upon conviction thereof shall be punished by a fine of not less than twenty-five dollars nor more than one hundrerl dollars. All fines imposed for violation of the provisions of this act shall be paid to the treasurer of the comty wherein the violation was committed and placed to the general fund of such county.

SEc. 4. That the State Commissioner of Horticulture and the county fruit inspectors under his supervision be charged with the enforcement of this act, with the assistance of the prosecuting attorney.

SEc. 5. It shall be the duty of the ehemist of the State Agrieultural Experiment Station to correctly analyze, without extra compensation and without extra charge to the state other than the necessary expenses, all substances and compounds user or offered for sale for spraying trees and plants, that the State Commissioner of Horticulture may send for analysis, and report to him without unnecessary delay the result of any analysis so made; any such chemist shall assist him in prosecuting violations of the law, by giving testimony, expert or otherwise. Approced by the Governor February 26, 1901. 


RETURN TO the circulation desk of any University of California Library

or to the

NORTHERN REGIONAL LIBRARY FACILITY Bldg. 400, Richmond Field Station

University of California

Richmond, CA 94804-4698

ALL BOOKS MAY BE RECALLED AFTER 7 DAYS

- 2-month loans may be renewed by calling (510) 642-6753

-1-year loans may be recharged by bringing books to NRLF

- Renewals and recharges may be made 4 days prior to due date

\section{DUE AS STAMPED BELOW}

\section{MAY 292003}

\section{JUL 292003}




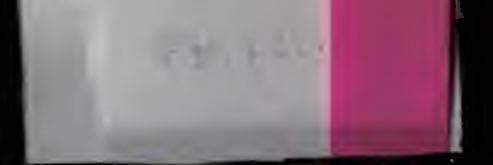

